\title{
Recovery of acidified Sudbury, Ontario, Canada, lakes: a multi-decade synthesis and update.
}

\begin{tabular}{|r|l|}
\hline Journal: & Environmental Reviews \\
\hline Manuscript ID & er-2018-0018.R1 \\
\hline Danuscript Type: & Review \\
\hline Aubmitted by the \\
Complete List of Authors: & $\begin{array}{l}\text { Keller, Wendel (Bill); Laurentian University } \\
\text { Heneberry, Jocelyne; Ontario Ministry of the Environment and Climate } \\
\text { Change, Cooperative Freshwater Ecology Unit; Laurentian University } \\
\text { Edwards, Brie A.; Ontario Ministry of the Environment and Climate } \\
\text { Change, Cooperative Freshwater Ecology Unit; Laurentian University }\end{array}$ \\
\hline Keyword: & acidification, lakes, biota, recovery, Sudbury \\
\hline & \\
\hline
\end{tabular}

\section{SCHOLARONE Manuscripts}


1 Recovery of acidified Sudbury, Ontario, Canada, lakes: a multi-decade synthesis and 2 update.

4 W. (Bill) Keller, Cooperative Freshwater Ecology Unit, Vale Living with Lakes Centre, 5 Laurentian University, Sudbury, Ontario, P3E 2C6, Canada

6 Jocelyne Heneberry, Ontario Ministry of the Environment Conservation and Parks, Cooperative

7 Freshwater Ecology Unit, Vale Living with Lakes Centre, Laurentian University, Sudbury,

8 Ontario, P3E 2C6, Canada

9 Brie A. Edwards, Ontario Ministry of the Environment Conservation and Parks, Cooperative 10 Freshwater Ecology Unit, Vale Living with Lakes Centre, Laurentian University, Sudbury, 11 Ontario, P3E 2C6, Canada

13 Correspondence:

14 W. (Bill) Keller, Cooperative Freshwater Ecology Unit, Vale Living with Lakes Centre, 15 Laurentian University, Sudbury, Ontario, P3E 2C6, Canada

16 Phone: 7056713858

17 Fax: 7056713857

18 Email: bkeller@laurentian.ca

19

20 Word count 14373 
21 Abstract: The Sudbury region of northeastern Ontario, Canada, provides one of the world's best

22 examples of the resilience of aquatic ecosystems after reductions in atmospheric contaminant

23 deposition. Thousands of lakes around the Sudbury metal smelters were badly damaged by acid

24 deposition. Lakes closest to the smelters were also contaminated by metal-particulates. However,

25 large reductions in atmospheric $\mathrm{SO}_{2}$ and metal emissions starting in the early 1970's have led to

26 widespread chemical improvements in these lakes, and recovery has been observed for various

27 aquatic biota. Studies of Sudbury area lakes are advancing our understanding of chemical and

28 biological lake recovery; however, recovery is a complicated process and much remains to be

29 learned. Biological recovery has often been slow to follow chemical recovery, and it has become

30 apparent that the recovery of lakes from acidification is closely linked to interactions with other

31 large-scale environmental stressors like climate change and Ca declines. Thus, in our multiple

32 stressor world, recovery may not bring individual lakes back to their exact former state.

33 However, with time, substantial natural biological recovery toward typical lake communities can

34 be reasonably expected for most but not necessarily all biota. For organisms with limited

35 dispersal ability, particularly fish, human assistance may be necessary to re-establish typical

36 communities. In lakes where food webs have been severely altered, re-establishment of typical

37 diverse fish communities may in fact be an important element aiding the recovery of other

38 important components of aquatic ecosystems including zooplankton and benthic

39 macroinvertebrates. In the lakes closest to the smelters, where historically watersheds as well as

40 lakes were severely damaged, the recovery of aquatic systems will be closely linked to ongoing

41 terrestrial recovery and rehabilitation, particularly through the benefits of increased inputs of

42 terrestrially-derived organic matter. The dramatic lake recovery observed in the Sudbury area

43 points to a brighter future for these lakes. However, continued monitoring will be needed to 
44 determine future changes and help guide the management and protection of Sudbury area lakes

45 in this multiple-stressor age.

46 Keywords. Acidification, lakes, biota, recovery, Sudbury

\section{Introduction}

The mining and smelting of metals in the Sudbury, Ontario, Canada area began in the late 1800's (Winterhalder 1995a) and over time the Sudbury smelters became one of the world's

51 largest sources of sulphur dioxide $\left(\mathrm{SO}_{2}\right)$ emissions, releasing $\sim 2500$ kilotonnes per year in the

52 1960's. As well, the smelters emitted large quantities of metal (particularly $\mathrm{Ni}$ and $\mathrm{Cu}$ )

53 particulates. The acidification of surface waters in northeastern Ontario near the Sudbury,

54 Ontario, metal-smelting complex was first identified in the 1960's (Gorham and Gordon 1960;

55 OWRC 1970) and by the mid 1970's it was known that lake acidification extended for a 56 considerable distance from the Sudbury smelters (Beamish and Harvey 1972; Beamish 1974;

57 Conroy et al. 1974; Beamish et al. 1975; Conroy and Keller 1976; Conroy et al. 1976). By the 58 mid 1970's, aquatic science programmes, largely led by the Ontario Ministry of the Environment 59 (now the Ontario Ministry of Environment, Conservation and Parks), were in place to assess the 60 extent and nature of aquatic acidification damage in northeastern Ontario (Conroy et al. 1976; 61 Dillon et al. 1979), programmes that expanded during the 1980's.

Based on large-scale chemistry surveys conducted in the 1980's it was estimated that over 7,000 lakes in a $17,000 \mathrm{~km}^{2}$ area had been acidified to $\mathrm{pH}<6.0$ by the Sudbury smelter 64 emissions (Neary et al. 1990). In the lakes closest to Sudbury, severe metal contamination 65 (especially $\mathrm{Cu}$ and $\mathrm{Ni}$ ) of lakewaters (Conroy et al. 1976, 1978) and sediments (Semkin and 
Kramer 1976; Conroy et al. 1978) had accompanied acidification. As studies progressed, it became apparent that widespread acidification damage had occurred to many biological components of aquatic ecosystems including fish (Keller1978; Matuszek et al. 1992), benthic invertebrates (Conroy et al. 1976; Roff and Kwiatkowski 1977; Stephenson and Mackie 1986), zooplankton (Spules 1975, 1977; Roff and Kwiatkowski 1977; Yan and Strus 1980; Keller and Pitblado 1984; Yan and Geiling 1985; Yan et al. 1985; MacIsaac et al. 1987; Yan et al. 1988), benthic filamentous algae (Keller et al. 1980; Vandermeulen et al. 1993) and phytoplankton (Conroy et al. 1976; Kwiatkowski and Roff 1976; Yan and Stokes 1978; Yan 1979; Nicholls et al. 1992). This biological damage, at various aquatic trophic levels, included the loss of acidsensitive species and reduced community richness. However, along with the documentation of large-scale aquatic damage came the realization that lakes were already showing increases in $\mathrm{pH}$ and reductions in $\mathrm{Cu}$ and $\mathrm{Ni}$ concentrations in the 1980's (Hutchinson and Havas 1986; Keller and Pitblado 1986) in response to large reductions in $\mathrm{SO}_{2}$ and metal emissions at the Sudbury smelters in the early 1970's as well as declines in overall North American sulphur emissions. The focus of aquatic studies in the Sudbury area began to change, from damage assessment to investigating patterns of chemical and biological recovery. Additional emission reduction programmes in the late 1970s and early 1990's, which, along with the earlier cuts, achieved > 90\% reductions from previous peak levels of $\mathrm{SO}_{2}$ (see for example Fig. 2 in Keller 2009) and metal emissions, gave reason for guarded optimism for the future of northeastern Ontario lakes. Expectations for ecosystem recovery were positive; however, the actual knowledge of chemical and biological recovery processes was limited, and ongoing study was essential to track and understand long-term recovery patterns. While much has been learned, many uncertainties remain. 
This paper summarizes findings from Sudbury area lake studies over the last four and a

90 half decades. We document the current understanding of chemical and biological lake recovery

91 in the Sudbury area. We also describe some of the complexities of assessing recovery in light of

92 the known interactions with other important stressors, such as climate change and Ca declines.

\section{Sudbury lakes}

There is no "typical" Sudbury lake (Keller 1992). Lakes affected by the Sudbury smelter emissions fall along a continuum, from very remote, dilute, oligotrophic systems in highly acidsensitive terrain distant from Sudbury, to urban lakes close to the smelters and subjected to urban stressors such as nutrient and road salt inputs as well as atmospheric metal and acid deposition. This diversity of Sudbury lakes greatly amplifies the broad, international value of the Sudbury lake monitoring programmes. Relatively pristine lakes distant from the smelters are similar to the dilute, acid-sensitive lakes that have typically been affected by long-range acid deposition in other areas of North America and Europe (Garmo et al. 2014) offering valuable comparisons for other regions. Because of these similarities Norwegian scientists visited some of these lakes in the 1990's to develop and test methods of assessing lake recovery, in anticipation of impending

105 benefits from European sulphur emission controls (Gunn and Sandoy 2003). The more urbanized

106 Sudbury lakes offer opportunities to better understand the aquatic effects of interacting multiple 107 stressors in heavily developed landscapes (Gunn and Keller 1995; Valois et al. 2011). The lakes 108 closest to the Subury smelters that were historically highly acidic and metal-contaminated offer 109 valuable comparisons to other lake regions directly affected by metal smelters in other areas of 
110 Canada (Alpay 2006; Jeziorski et al. 2013) and the world (Moiseenko 1994), and lakes affected

111 by other industrial sources of acid and metal-contamination (Manca et al. 2016).

113 temporal scales. "Intensive" monitoring lakes were sampled for water chemistry and plankton at

114 least monthly during the ice-free season. Regular sampling on some lakes started as early as

115 1973. In fact, one of the key Intensive monitoring lakes, Clearwater, has the longest continuous

116 monitoring record of any acid lake in the world, to our knowledge. Additional Intensive lakes

117 were added to the programme during the 1980's and 1990's to better cover the range of lake

118 types affected by the Sudbury emissions. A few of the Intensive lakes (Fig. 1) were 119 experimentally limed in the 1970's (Lohi, Middle, Hannah) or the 1990's (Whirligig, Little 120 Whitepine). "Extensive" monitoring lakes were sampled only once per summer, primarily for 121 water chemistry with periodic plankton sampling. The focus of the Extensive programme was to 122 document the spatial extent of effects on Sudbury area lakes, and determine temporal changes on 123 a broad scale. The initial Extensive survey was conducted on 209 lakes during 1974-1976 124 (Conroy et al. 1978). During 1981-1983 these lakes were again sampled (Pitblado and Keller 125 1984) and additional lakes were surveyed $(n=250)$. Since 1981, a subset of acidic lakes, 126 including the 42 lakes considered here, has been sampled annually (Table 1, Fig. 1). The 127 analyses of long-term chemistry patterns presented here (Fig. 2) are based on the Extensive 128 monitoring lakes (time series for $\mathrm{pH}, \mathrm{SO}_{4}, \mathrm{Ca}$ and dissolved organic carbon (DOC) are presented 129 in Tables A1 to A4 of the Appendix); however, changes in many of the Intensive monitoring 130 lakes and other Sudbury area lakes are described and discussed in the text. 


\section{Chemical and physical changes with recovery}

134 Acidity and sulphate

Since the initial documentation of damage, there has been dramatic chemical recovery of 136 acidified lakes near Sudbury, resulting from smelter emission reductions (e.g. Dillon et al. 1986;

137 Hutchinson and Havas 1986; Keller and Pitblado 1986; Keller et al. 1986; 1992a; 1999a, b; 138 2001a; Woodfine and Havas 1995). Changes included the expected declines in acidity and $\mathrm{SO}_{4}$ 139 concentrations (Figs. 2a, b). While there are still many acidified lakes around Sudbury and 140 elsewhere in Ontario (Jeffries et al. 2003), changes in the acidity of Sudbury lakes have been 141 dramatic (Fig. 2a).

Changes in lake $\mathrm{pH}$ (and other chemical parameters discussed in subsequent sections) 143 over the monitoring record were examined using linear mixed effect models (LMM). Models 144 were fit using the lme4 package (version 3.4.4, Bates et al. 2017) in the R statistical environment 145 (R 3.1.3, https://www.r-project.org/) and the structure of each LMM was identical for all 146 parameters: with change over time (monitoring years 1-35) as a random effect and grouped by 147 lake. The significance of lake-specific changes was assessed by deriving the $95 \%$ confidence 148 intervals of their lake specific slope parameters. Additional details are provided in Fig. 2. Of the 14942 Extensive monitoring lakes considered here, all had overall pH increases since 1981. In 1981, 150 all these lakes had $\mathrm{pH}<6.0$ a level below which toxicity occurs to sensitive aquatic biota 151 (Keller et al. 1990a; Havens et al. 1993; Holt and Yan 2003) and $26(62 \%)$ had pH $<5.0$. By 1522015 , none of the lakes had $\mathrm{pH}<5.0$ and $24(57 \%)$ had $\mathrm{pH}>6.0$. 
Surprisingly, some of the most dramatic declines in acidity have been observed in

154

155

156

157

158

159

160

161

162

163

164

165

166

167

168

169

170

171

172

173

174

175

severely damaged urban lakes close to the Sudbury smelters, such as Clearwater and Crooked lakes (Figs. 1, 2a). The rapid recovery of such sulphur and metal-rich lakes is likely related to alkalinity generation from microbial reduction of the abundant sulphur and metals (White et al. 1997). Such alkalinity generation in urban lakes may be enhanced by nutrient inputs from shoreline development (Keller et al. 1999c); however, dramatic declines in acidity have also been observed in undeveloped lakes (e.g. Daisy Lake, Fig. 1). The Sudbury-area lakes that have shown the least increases in $\mathrm{pH}$ include headwater lakes located on weathering-resistant, soilpoor, quartzite ridges up to $\sim 50 \mathrm{~km}$ southwest and $\sim 110 \mathrm{~km}$ north of Sudbury, such as Nellie and Sunnywater lakes, respectively (Figs. 1, 2a). In addition to being located in highly acidsensitive terrain, these deep lakes with comparatively small watersheds have water retention times of several decades. Thus, a slow response to reductions in sulphur deposition is not surprising given the important influence of flushing time on lake response (Arnott et al. 2003; Larssen et al. 2003).

While water quality issues continue, the spatial extent of the Sudbury influence on lakes is now only a fraction of what it was in the past. All Sudbury area Extensive monitoring lakes have shown declines in $\mathrm{SO}_{4}$ concentrations since 1981 (Fig. 2b). In the mid 1970's elevated lakewater $\mathrm{SO}_{4}$ concentrations $\left(>10 \mathrm{mg} \mathrm{L}^{-1}\right.$ ) were detectable to $\sim 140 \mathrm{~km}$ from Sudbury (Conroy et al. 1978). Such elevated $\mathrm{SO}_{4}$ concentrations now only occur in a few lakes very close $(<10$ $\mathrm{km}$ ) to the Sudbury smelters (Fig. 3a), although concentrations over $5 \mathrm{mg} \mathrm{L}^{-1}$ extend to $\sim 50 \mathrm{~km}$, and lakewater $\mathrm{SO}_{4}$ concentrations out to $\sim 90 \mathrm{~km}$ from Sudbury still sometimes slightly exceed concentrations in lakes $250 \mathrm{~km}$ to the southeast, near Dorset, Ontario (Yan et al. 2008a) that reflect regional background levels as affected by long range atmospheric transport (Fig. 3a). 


\section{$177 \quad$ Metals}

While lakewater metal $(\mathrm{Cu}, \mathrm{Ni})$ concentrations have also declined greatly in Sudbury area lakes, residual metal contamination in water and sediments persists in the lakes closest to Sudbury, and will likely continue for many years (Nriagu et al. 1998; Keller et al. 1999b). Some of the lakes close to Sudbury are also affected by urban stresses such as road salting and nutrient inputs from shoreline development (Gunn and Keller 1995; Pearson et al. 2002; Tropea et al. 183 2011), affecting metal toxicity and complicating patterns of recovery (Celis-Salgado et al. 2016). In the 1970's metal $(\mathrm{Ni}, \mathrm{Cu})$ concentrations in lakewaters exceeding $30 \mu \mathrm{g} \mathrm{L}^{-1}$ for $\mathrm{Ni}$ and $25 \mu \mathrm{g}$ $\mathrm{L}^{-1}$ for $\mathrm{Cu}$ were detected to $\sim 40$ and $80 \mathrm{~km}$, respectively, from Sudbury (Conroy et al. 1976). Currently (2015), elevated concentrations of these metals, exceeding Ontario Guidelines (MOEE 1994) for surface waters ( $\mathrm{Ni} 25 \mu \mathrm{g} \mathrm{L}^{-1}, \mathrm{Cu} 5 \mu \mathrm{g} \mathrm{L}^{-1}$ ) are restricted to lakes within $\sim 20 \mathrm{~km}$ of Sudbury. However, slightly elevated $\mathrm{Ni}$ and $\mathrm{Cu}$ concentrations are still detectable in some lakes up to $\sim 50 \mathrm{~km}$ from Sudbury (Figs. 3b, 3c), a legacy of past widespread metal deposition on the 190 landscape.

In contrast to $\mathrm{Cu}$ and $\mathrm{Ni}$, concentrations of total $\mathrm{Al}$ (Fig. 3d) do not show a relationship to 192 distance from the smelters, since acid-leaching of soils and increased lake acidity, not direct 193 atmospheric deposition, were the major factors causing elevated Al concentrations (Keller et al. 194 2003) in acidified lakes. While Al concentrations have greatly declined through time, they are 195 still (2015) highly correlated with $\mathrm{pH}\left(r_{s}-0.78, p<0.05\right)$. The Extensive monitoring lakes with 196 the highest recent $\mathrm{Al}$ concentrations $\left(140-258 \mu \mathrm{g} \mathrm{L}^{-1}\right)$ all still have $\mathrm{pH}<5.6$. 


\section{Calcium}

Unexpectedly, large declines in $\mathrm{Ca}$ concentrations (Fig. 2c) were also observed in Sudbury lakes as acidity decreased (Keller et al. 2001b) a pattern that was soon after documented broadly in Precambrian Shield lakes across central and northern Ontario (Jeziorski et al. 2008; Edwards et al. 2009). Ca concentrations in many formerly acidified lakes near Sudbury are now much lower than diatom-inferred background conditions determined from paleolimnological analyses of sediment cores (Keller et al. 2001b, 2003). Declines in lakewater Ca concentrations averaging 55\% (49 to 67\%) have occurred in all Extensive monitoring lakes since annual sampling commenced in 1981 (Fig. 2c). Declines in Ca (1981 vs 2015) were significantly correlated $\left(r_{s}=0.84, p<0.05\right)$ with declines in $\mathrm{SO}_{4}$. Considering charge balances $\left(\mu \mathrm{eq} \mathrm{L} \mathrm{L}^{-1}\right)$ the declines in $\mathrm{Ca}$ on average balance $46 \%$ of the declines in $\mathrm{SO}_{4}(27$ to $72 \%$ in individual lakes). Almost all (40) of the 42 Sudbury area Extensive monitoring lakes considered here (Fig. 1) now have $\mathrm{Ca}<2 \mathrm{mg} \mathrm{L}^{-1}$ (Fig. 2c), and most (33) of these lakes now have Ca concentrations below 1.5 mg L ${ }^{-1}$, an approximate threshold for damage to the most sensitive Daphnia species and chronic stress in native crayfish in Precambrian Shield lakes (Ashforth and Yan 2008; Jeziorski et al. 2008; Cairns and Yan 2009; Edwards et al. 2015). However, the effect of Ca declines on aquatic species is a complex issue, involving differing species sensitivities, lethal and sub-lethal toxicity, and altered predatory interactions (Cairns and Yan 2009; Jeziorski et al. 2012; Riessen et al. 2012; Azan and Arnott 2017; Jeziorski and Smol 2017). The only two Extensive monitoring lakes with $\mathrm{Ca}$ still above $2 \mathrm{mg} \mathrm{L}^{-1}$ are urban lakes (Clearwater, Tilton; Fig. 1). Ca concentrations in these lakes may have been affected by urban influences such as local watershed development and dust control applications of $\mathrm{CaCl}_{2}$ to gravel roads. 

in Ontario (Jeziorski et al. 2014) inducing a shift from Ca-rich daphnids to Ca-poor Holopedium,

222 and are likely also affecting other biota. Because of its moderating role on the sensitivity of biota 223 to other stressors like acidity, metals, UV-B irradiance, and temperature (Skeffington and Brown 224 1992; Hessen and Alstad Rukke 2000; Ashforth and Yan 2008) declines in Ca concentrations are 225 of major concern (Jeziorski and Smol 2017) and need to be closely monitored (Keller 2009). 226 Based on estimated weathering rates, further declines in the $\mathrm{Ca}$ concentrations of northern 227 Ontario lakes are likely (Watmough and Aherne 2008).

\section{Dissolved organic carbon}

Similar to observations in many areas of Europe and North America (Garmo et al. 2014), dissolved organic carbon (DOC) concentrations have increased in many Ontario lakes (Keller et al. 2008; Yan et al. 2008b) including those around Sudbury (Fig. 2d). Such "browning” can have

233 dramatic ecological effects (Williamson et al. 2015). While changes in atmospheric deposition 234 chemistry after sulphur emission reductions explain much of the widely observed DOC increase 235 in surface waters in many areas of the world (Monteith et al. 2007), recent DOC increases in 236 Ontario lakes, including lakes near Sudbury, also appear to be related to a warming climate 237 (Keller et al. 2008). Dramatic increases in lake DOC have generally accompanied recovery from 238 acidification (Dixit et al. 2001; Keller et al. 2003, 2005); however, DOC increases have also

239 been observed in northeastern Ontario lakes that never acidified (Keller 2007), pointing to 240 changes in soil solution chemistry rather than in-lake processes as a dominant factor affecting 241 lake DOC. 
Increased UV-B penetration resulting from acidification-related DOC declines likely

243

244

245

246

247

248

249

250

251

252

253

254

255

256

257

258

259

260

261

262

263

264

contributed to the biological damage observed in very clear, low DOC lakes (Yan et al. 1996a;

Keller et al. 2003; Persaud and Yan 2003). DOC increases in recovering lakes have substantially reduced DOC-inferred UV-B penetration (Dixit et al. 2001). Since 1981, DOC has increased in all but the five clearest (DOC $<1.5 \mathrm{mg} \mathrm{L}^{-1}$ ) Extensive monitoring lakes (Sunnywater, Nellie, Ruth Roy, OSA, Marjorie; Fig. 2d). Considering the overall DOC changes between 1981 and 2015, summer lake waters now contain 1.2 to 326 (average 51$)$ tonnes more DOC $(n=38$, lake volume not available for 4 lakes) than they did several decades ago. Temporal changes (1981 vs $2015)$ in DOC concentrations were significantly correlated with changes in $\mathrm{SO}_{4}\left(r_{s}=-0.60, p<\right.$ 0.05) again suggesting that declines in sulphur deposition were a major factor affecting DOC increases. While generally, Ontario lakes are not at great risk of damage by UV-B irradiance (Molot et al. 2004) some very clear Sudbury area lakes may be exceptions. However, in 2015, only six of the 42 Extensive monitoring lakes had DOC $<2 \mathrm{mg} \mathrm{L}^{-1}$, a level below which UV attenuation is greatly reduced (Williamson et al. 1996).

In the relatively small $(<500$ ha) lakes that cover the northern Ontario landscape, lake clarity/DOC has a dominant influence on determining lake thermal structure (Snucins and Gunn 2000), including the amount of cold-water habitat (Keller et al. 2005) and epilimnion thickness (Keller et al. 2006). Even with a generally warming climate, the amount of cold-water habitat in some Sudbury area lakes has been observed to increase with increased DOC (Keller et al. 2005; Tanentzap et al. 2008).

Complexing by organic compounds is an important factor moderating the toxicity of metals, especially copper (Park et al. 2009; Cloran et al. 2010; Cuss et al. 2010; Taylor et al. 2015a) to aquatic organisms. Thus, it is likely that DOC increases are helping reduce metal 
265 266

267

toxicity in Sudbury area lakes and that such benefits will increase as terrestrial systems recover further, re-building organic soils and contributing increased organic matter inputs to lakes.

\section{Total phosphorus and nitrate}

All but six of the Extensive monitoring lakes did not show any evidence of temporal changes in total phosphorus (TP) concentrations based on analyses of slopes over the 1981-2015 period. This conclusion is not surprising perhaps, since shoreline development is not heavy on any of the Extensive lakes and most have none, although many lakes in south-central Ontario have declined in TP even with increases in human activity (Eimers et al. 2009) from causes that are not clear. More heavily urbanized lakes in Sudbury have shown evidence of cultural eutrophication based on comparisons with background conditions estimated by hindcasts from watershed TP models (Gunn and Keller 1995) and inferred from paleolimnological analyses of diatoms in sediment cores (Tropea et al. 2011). Lake and watershed characteristics do not point to any obvious explanation for the apparent decreases (Sans Chambre, Telfer) or increases (Bob, Klock, Tillie, Crooked) in a few of the Extensive lakes. It is recognized, however, that the use of single summer samples for TP analyses may limit the ability to detect trends since substantial biological TP (and nitrogen) utilization may already have occurred at the time of sampling. Future, more rigourous assessment of trends in nutrients, considering lakes with more frequently collected, seasonal data, such as the Intensive lakes might be more revealing.

Atmospheric Deposition of $\mathrm{N}$ in the Sudbury area is primarily from long-range sources since the Sudbury smelters have never been a large N source (Keller et al. 2003). While nitrate $\left(\mathrm{NO}_{3}\right)$ can sometimes be an important factor in lake acidification, the main driver of widespread 
287 recovery from aquatic acidification in Europe and North America has been declines in sulphur 288 deposition, although the relative importance of $\mathrm{NO}_{3}$ to acidification may change with reduced 289 sulphur deposition (Garmo et al. 2104). The dominant trend in the Extensive lakes has been a 290 decline in $\mathrm{NO}_{3}$ concentrations (28 lakes) with no trend observed in 14 lakes. This generally 291 agrees with other North American and European observations indicating either declines or no 292 change in surface water $\mathrm{NO}_{3}$ concentrations in recent decades (Garmo et al. 2014; Vuorenmaa et 293 al. 2018).

\section{Biological changes with recovery}

The richness and community composition of phytoplankton communities in the Sudbury area have generally changed relatively rapidly (within decades) after chemical recovery. During recovery, phytoplankton communities have typically increased in species richness and shifted

301 from dominance by acid-tolerant dinoflagellates and chlorophytes to increased abundance of 302 chrysophytes, diatoms and cyanobacteria (Nicholls et al. 1992; Havas et al. 1995; Findlay 2003;

303 Graham et al. 2007; Winter et al. 2008; Bergeron 2012).

Paleolimnological studies utilizing diatoms and scaled chrysophytes have been instrumental in revealing both the patterns of acidification of Sudbury lakes and their recovery

306 (Dixit et al. 1988, 1989, 1992a, 1992b, 1993, 1995, 1996; Smol et al. 1998). While evidence of 307 recovery was widely observed, changes were not always towards inferred background 
308

309

310

311

312

313

314

315

316

317

318

319

320

321

322

323

324

325

326

327

conditions. In Sudbury area lakes with residual metal-contamination, communities of diatoms have not begun to recover (Tropea et al. 2010). As well, even in lakes that were not heavily metal contaminated, recovery trajectories do not necessarily track towards pre-industrial diatom assemblages (Sivarajah et al. 2016, 2017) likely because of climate warming effects.

The benthic filamentous algae Zygogonium which often proliferated along shorelines of very clear, acid lakes was observed to decline dramatically with $\mathrm{pH}$ increases in Swan Lake (Fig. 1 ), giving way to more diverse benthic algal communities (Vandermeulen et al. 1993).

\section{Zooplankton}

Recovery of zooplankton communities has been particularly well studied in Sudbury area lakes and elsewhere. There have been two reviews examining patterns of zooplankton community recovery from acidification (Keller and Yan 1998; Gray and Arnott 2009). Substantial zooplankton community recovery has often been observed within decades of water quality improvements. Typically, recovery included re-establishment of acid-sensitive crustacean species including Daphnia mendotae, Epischura lacustris, Skistodiaptomus oregonensis, Eubosmina longispina, and others, leading to increased species richness (Keller and Yan 1991; Keller et al. 1992b; Locke et al. 1994; Keller et al. 2002; Holt and Yan 2003; Keller et al. 2007). Among rotifers, with increased $\mathrm{pH}$ the acid-tolerant Keratella taurocephela typically declined and acid-sensitive species including Keratella cochlearis, Polyarthra sp., and Conochilus sp. increased in importance (MacIssac et al. 1986; Keller et al. 1992c).

Dispersal does not seem to greatly constrain recovery in lake-rich regions where there are many colonist sources (Watson et al. 1999; Pollard et al. 2003; Keller et al. 2007; Audet et al. 
2013: Yan et al. 2016). Dispersal may, however, be a more important factor affecting recovery in lakes that are isolated from colonist sources by distance and/or elevation (Keller and Yan 1998; Gray and Arnott 2009, 2011). While most zooplankton species (both rotifers and crustaceans) seem to re-establish comparatively quickly (MacIsaac et al. 1986; Keller at al. 1992c; Havas et al. 1995; Keller et al. 2002), some species including hypolimnetic forms (Daphnia longiremis, Cyclops scutifer), and the so called "glacial opportunists" including Senecella calanoides, Limnocalanus macrurus, Leptodiaptomus sicilis and Diaptomus ashlandi appear to be much less able to disperse between waterbodies (Keller and Yan 1998; Gray and Arnott 2009).

Improved water quality does not guarantee zooplankton community recovery even if dispersal is not limiting, since "biological resistance" (sensu Keller and Yan 1998) as well as chemical factors can be important in recovery processes (Keller and Yan 1998; Yan et al. 2003; Gray et al. 2012). Established acid-tolerant zooplankton communities may resist invasions by acid-sensitive species, delaying community recovery (Binks et al. 2005; Derry and Arnott 2007). In lakes where planktivorous fish were eliminated by acidification, zooplankton community structure can be controlled by invertebrate predators such as Chaoborus (Yan et al. 1991; Keller et al. 2002, MacPhee et al. 2011) and water beetles (Arnott et al. 2006) which expand in the absence of fish. In such cases the reintroduction of planktivorous fish is required to re-establish a more typical vertebrate-based predation system. However, in the absence of piscivores, predation by abundant planktivorous fish such as small yellow perch (Perca flavescens) can itself be a constraint to zooplankton recovery (Keller and Yan 1998; Yan et al. 2004; Webster et al. 2013). Ultimately the development of typical zooplankton communities will likely depend on the re-establishment of diverse fish communities containing both planktivores and piscivores (Valois et al. 2010, 2011; Webster et al. 2013). 
In the lakes closest to Sudbury, residual metal contamination is also still a factor

354 negatively affecting zooplankton communities (Yan et al 2004; Valois et al. 2011; Labaj et al. 355 2015; Taylor et al. 2016b) as it has been for many decades (Yan et al. 1996b). Interestingly, in 356 urban Sudbury lakes with $\mathrm{Ca}$ and $\mathrm{Na}$ levels elevated because of anthropogenic activities, the 357 sensitivity of Daphnia to metals is considerably reduced (Celis-Salgado et al. 2016) in 358 comparison to lakewaters without elevated $\mathrm{Ca}$ and $\mathrm{Na}$.

\section{Benthic macroinvertebrates}

There are many examples of at least partial recovery of benthic macroinvertebrate

362 communities in Sudbury area lakes after reductions in acidity, including soft sediment littoral 363 and profundal areas (Gunn and Keller 1990; Griffiths and Keller 1992; Reasbeck 1997; Babin364 Fenske et al. 2012) and rocky near-shore habitats (Gunn and Keller 1990; Snucins 2003). 365 Relatively rapid recovery of benthic macroinvertebrate communities is not surprising given the 366 relative mobility of many species, especially the winged stages of insects. However, there are 367 some macroinvertebrates (e.g. snails, clams, amphipods, crayfish) with more limited dispersal 368 abilities. Natural re-establishment of such species may be a very slow process unless there are 369 residual populations persisting in refuges within a lake or its watershed. Dispersal, if slow, does 370 however occur for non-mobile species by passive means including transport by humans and 371 wildlife (Kappes and Haase 2012). Snails (Gastropoda: Fossaria exigua, Heliosoma anceps, 372 and Physella sp.) and amphipods (Hyalella azteca) were observed to colonize a small, newly373 created Sudbury area lake within 2 years, with waterfowl being the suspected vector of 374 introductions (Watson et al. 1999). Little is known about aquatic macrophytes in Sudbury 
375 lakes, however, if macrophyte abundance increases in recovering lakes positive responses in 376 benthic macroinvertebrate communities will likely follow. The abundance of the amphipod, $H$. 377 azteca, is positively associated with the extent of littoral macrophyte cover in a number of Sudbury $378 \quad$ lakes (Kielstra et al. 2017).

The continuing low species richness of benthic macroinvertebrate communities in some 380 lakes near Sudbury is related to residual metal contamination of waters and sediments, which continues to affect biological communities in the lakes closest to Sudbury where metal 382 deposition was highest (Reasbeck 1997; Borgmann et al. 1998; Borgmann 2003; Wesolek et al. 2010a, b; Luek et al. 2013, 2015). Benthic macroinvertebrate communities in these lakes are characterized by absence or scarcity of taxa such as decapoda, mollusca, ephemeroptera, and 385 amphipoda, and an abundance of Chironomidae. The scarcity of large grazers such as amphipods and crayfish may lead to extensive periphyton accumulations (Heneberry 1997) that can affect the recovery of other invertebrates.

In the mid 1990's sediment concentrations of $\mathrm{Ni}$ and $\mathrm{Cu}$ still exceeded, often greatly,

389 Ontario Sediment Quality Guidelines for the protection of aquatic life (75 and $110 \mu \mathrm{g} \mathrm{g}^{-1}$ for $\mathrm{Ni}$ 390 and $\mathrm{Cu}$, respectively, MOEE 1993) out to $\sim 50 \mathrm{~km}$ from Sudbury (Keller et al. 2004). While 391 metal concentrations in surface sediments are generally declining (Borgmann et al. 1998; Tropea 392 et al. 2010) very high levels persist in some Sudbury lakes, with concentrations of $\mathrm{Ni}$ and $\mathrm{Cu}$ exceeding, sometimes far exceeding, $1000 \mu \mathrm{g} \mathrm{g}^{-1}$ (Tropea et al. 2010). Burial of contaminated 394 sediment with clean sediment may be a very slow process (Belzile and Morris 1995).

Additionally, even after reductions in chemical stress from contaminated water and sediments, in lakes with scarce or absent piscivores intensive predation by fish species such as 
397 yellow perch ( $P$. flavescens) can negatively affect the recovery of macroinvertebrate 398 communities (Wesolek et al. 2010; Luek et al. 2010, 2013, 2015). In lakes where food webs have 399 been badly altered by acidification, the re-establishment of typical fish communities may be 400 required to achieve recovery of benthic macroinvertebrate populations.

402 Fish

In a few cases such as Whitepine (Fig. 1) and Nelson lakes, small remnant populations of lake trout (Salvelinus namaycush) have increased dramatically in response to decreased lake 405 acidity (Gunn and Keller 1990; Casselman and Gunn 1992). However, when fish have been 406 extirpated, re-colonization is not likely unless there are direct connections between affected lakes

407 and other lakes that contain fish source populations. Intentional or unintentional introductions by 408 humans are a major cause of fish species expansions.

410 and smallmouth bass (Micropterus dolomieu) for experimental or fisheries management purposes 411 has been successful in formerly acidified lakes (Gunn et al. 1988; Gunn and Keller 1990; 412 Snucins and Gunn 2003; Luek et al. 2010). Re-establishment of acid-sensitive piscivores (lake 413 trout, smallmouth bass) in formerly acidified lakes has resulted in rapid and substantial declines 414 in very abundant acid-tolerant yellow perch populations (Gunn et al 1988; Gunn and Keller 415 1990; Gunn et al. 1990; Casselman and Gunn 1992; Luek et al. 2010) and likely contributed to 416 changes in populations of zooplankton and benthic macroinvertebrates through relaxed fish 417 predation (Gunn and Keller 1990; Keller et al. 1990b, 1992c; Griffiths and Keller 1992). 


\section{Lake and watershed liming}

In contrast to other acid-affected areas of the world, particularly Scandinavia (Olem et al.

421

422

423

424

425

426

427

428

429

430

1991; Henrikson and Brodin 1995), large-scale lake liming programmes were not implemented in Ontario because with an estimated 19,000 acidified lakes (Neary et al. 1990) liming as a lake management strategy was not considered to be economically or logistically feasible. As well, since liming is only a temporary interim step, not a solution, for the lake acidification problem, the focus in Ontario was on achieving effective controls on acid-causing emissions (Keller 2009). A small number of whole-lake liming activities were, however, conducted in Ontario to experimentally determine the responses of lake communities to reduced acidity (Dillon et al. 1979; Dodge et al. 1988; Keller et al. 1990c; Yan et al. 1995) or to assist with the restoration of a unique strain of brook trout, the aurora trout, which had been eliminated from its natural lakes by acidification (Snucins et al. 1995a, b).

In total, eight lakes were limed in Ontario, with seven in the Sudbury area. Lake liming activities were successful in increasing lake pH (Dillon et al 1979; Molot et al. 1990a; Yan et al. 1995) and also substantially reduced lakewater metal concentrations in the highly metalcontaminated lakes closest to Sudbury, although metal concentrations remained high (Dillon et al. 1979). Positive responses to liming were observed in many groups of organisms, including stocked lake trout (Gunn et al. 1990), phytoplankton (Molot et al. 1990b), littoral algae (Jackson et al. 1990), zooplankton (Keller et al. 1992c), and benthic macroinvertebrates (Keller et al. 1990b; Carbone et al. 1998). However, in most of the limed lakes re-acidification occurred relatively quickly, providing only limited opportunities to examine biological responses to neutralization. 
442 long-term re-acidification did not occur because of terrestrial reclamation programmes which 443 included liming of their watersheds (Lautenbach et al. 1995; Winterhalder 1996), an unplanned, 444 but very positive outcome. Watershed liming as an aquatic remediation measure has had limited 445 application in Ontario, although it has been widely applied to assist terrestrial reclamation efforts 446 on the metal-contaminated soils of the Sudbury area. Watershed liming experiments do 447 demonstrate that it is a useful practice to improve drainage water quality (Gunn et al. 2001) with 448 benefits for littoral lake biota (Gunn et al. 2016).

\section{Watershed effects on recovery}

Lakes and rivers are intimately linked to their watersheds and their chemistry can largely

452 be viewed as a watershed effect. Thus, Sudbury-area watersheds affected by atmospheric 453 deposition of sulphur and metals may negatively affect downstream chemistry, potentially for

454 very long periods, when there has been substantial contaminant storage in watershed soils and 455 wetlands (Nriagu et al. 1998; Keller et al. 1992a; Yan et al. 1996a; Szkokan-Emilson et al. 2013, 456 2014, 2017). Wet/dry cycles effectively oxidize and liberate quantities of acid and metals from 457 storage under anoxic conditions in wetlands, saturated soils, and lake sediments. Drought458 induced increases in the acidity and metal concentrations of streams and lakes can negatively 459 affect biota, including zooplankton (Arnott et al. 2001; Arnott and Yan 2002) and littoral 460 macroinvertebrates (Szkokan-Emilson et al. 2013, 2017). We do not know how long such events 461 may continue as an unfortunate legacy of the historically high contaminant deposition near 462 Sudbury, although it has been suggested that effects from metal-contaminated watersheds may 
463 persist for over a thousand years (Nriagu et al. 1998). Watershed-scale loss of soil ions, including

$464 \mathrm{Ca}$, also occurred as a result of acid deposition. Naturally thin and ion poor catchment soils in

465 Precambrian Shield regions, along with slow mineral weathering rates and further loss of ions

466 through vegetation removal with land-use changes combine to result in ongoing loss of $\mathrm{Ca}$ and

467 reduced inputs to lakes, that likely will continue for decades to come (Watmough and Aherne

468 2008). Time and continuing monitoring will tell.

469 Historically, clear-cut logging and $\mathrm{SO}_{2}$ fumigations from early metal smelting activities

470 damaged vegetation in a large area surrounding Sudbury, leading to large-scale erosion

471 (Winterhalder 1995a). Terrestrial damage left a large (17,000 ha) area barren of vegetation with

472 severely eroded soils, within a 72,000 ha semi-barren area, around the Sudbury smelters

473 (Winterhalder 1995a). However, with time, some natural re-vegetation has occurred

474 (Winterhalder 1995b,c) with reduced smelter emissions (Potvin et al. 1995), and large-scale land

475 restoration programmes including soil liming and tree planting have dramatically re-greened the

476 Sudbury area landscape (Lautenbach et al. 1995; Winterhalder 1996). In areas where watershed

477 soils and vegetation were historically disturbed, terrestrial recovery may be a very important

478 element assisting aquatic recovery. Increased organic matter export by streams from re-forested

479 areas is expected to have direct benefits to benthic invertebrates and ultimately to fish growth

480 (Wesolek et al. 2010a; Szkokan-Emilson et al. 2011; Tanentzap et al. 2014). Watershed re-

481 forestation can have physical as well as chemical effects on downstream lakes. Reductions in

482 wind speed related to a growing forest around Sudbury (Tanentzap et al. 2007) have been related

483 to reduced lake mixing and increased cold water habitat (Tanentzap et al. 2008). 
485

486

487

488

489

490

491

492

493

494

495

496

497

498

499

500

501

502

503

504

505

506

507

\section{Shifting reference conditions}

The fundamental nature of aquatic ecosystems in Ontario is changing in the face of multiple anthropogenic stressors including climate warming, Ca decline, and invasive species. Even in non-acidified Ontario lakes, chemistry and populations of zooplankton (Jeziorski et al. 2008; Yan et al. 2008; Palmer et al. 2011, 2013; Palmer and Yan 2013) and phytoplankton (Paterson et al. 2008) have changed in recent decades. Variability in observed temporal changes in lake plankton communities suggests that there can be strong heterogeneity in lake responses within and across regions, due to influences such as climate change (Arnott et al. 2003b).

Paleolimnological studies suggest that cladoceran and diatom communities in some recovering lakes are not moving back to their historical conditions, but rather they are moving to new states, likely because of climate warming (Labaj et al. 2016; Sivaraja et al. 2016, 2017).

Exotic invasive species are not yet widely distributed in inland lakes in Ontario; however, when present the exotic invader Bythotrephes has had dramatic effects on resident zooplankton populations (Boudreau and Yan 2003; Yan et al. 2008). Future expansions of this invader, likely with severe consequences for resident zooplankton, including reduced species richness and altered community structure (Strecker and Arnott 2005: Strecker et al. 2006), appear to be inevitable (Pagnucco et al. 2015). Range expansion of native species as well as exotic species can have dramatic effects on aquatic ecosystems. The northward expansion of bass ( $M$. dolomieu, Micropterus salmoides, Ambloplites rupestris) with a warming climate has the potential to significantly alter food webs in northern Ontario lakes, through heavy predation by bass on littoral food resources (Vander Zanden et al. 2004; Alofs and Jackson 2015). Recovering lakes without established fish communities and lacking top predators may be particularly at risk of invasion (Alofs and Jackson 2014). Climate change is also predicted to threaten the re- 
508 establishment and persistence of many native cool- and cold-water fish species, further 509 increasing the invasibility of northern lakes (Edwards et al. 2016; Van Zuiden et al. 2016).

510

511

512

513

514

515

516

517

518

\section{Summary}

Assessments of recovery must therefore consider this changing baseline, since the use of outdated reference data sets can substantially alter conclusions (Palmer et al. 2013). The choice of recovery metrics, and the use of multiple metrics is also important since different metrics vary in their detection sensitivity (Yan et al. 1996c) and can also lead to different conclusions (Keller et al. 2002; Gray and Arnott 2009). While much biological recovery has been observed in lakes near Sudbury, current assessments of the degree of recovery for various groups of biota are needed to gauge the actual extent and completeness of community recovery to date. Such assessments will need to be done against a background of changing reference conditions.

Once viewed as an international icon of environmental devastation, the Sudbury area now provides one of the best examples in the world of successful environmental restoration and recovery. Sudbury area studies have given a powerful demonstration of the environmental benefits of air pollution controls. Long-term monitoring of lakes in the region has shown remarkable chemical improvements after very large reductions of sulphur and metal emissions from area smelters and reduced acid deposition from long-range sources. Because of the large, relatively early regional sulphur emission reductions, lakes in the Sudbury area allowed documentation of the lake recovery process before the implementation of substantial emission controls in other areas. This evidence of aquatic ecosystem recovery was crucial in establishing the necessity of sulphur emission controls during the international debates about the effects of 
530 acid deposition and the need for action. Results from Sudbury area lakes have also led to the

531 development of a number of conceptual models of chemical and biological recovery processes

532 (Keller and Yan 1998; Yan et al. 2003; Keller et al. 2007) that continue to guide international

533 lake recovery studies. While the major contribution of Sudbury lake studies has been to

534 acidification research, these long-term data series, especially for zooplankton, have also had

535 substantial additional value for limnology in general. For example, Sudbury lake monitoring data

536 have helped advance the understanding of broad ecological issues related to relationships of

537 aquatic community change with environmental change (Helmus et al. 2010; Shurin et al. 2010;

538 Lamothe et al. 2018), and have allowed real-world validation of metal toxicity models for

539 aquatic invertebrates (Khan et al. 2012; Stockdale et al. 2014; Balistrieri et al. 2015).

541 groups of organisms, has followed chemical recovery. However, in some lakes recovery from

542 acidification and metal contamination is not yet complete, and recovery processes are

543 complicated by interactions with other large-scale environmental stressors like climate change

544 and $\mathrm{Ca}$ decline. Lake communities may not return exactly to their pre-acidification state because

545 of the influence of such large-scale stressors. In severely damaged lakes where food webs were

546 greatly altered, reintroduction of key fish species may be necessary to achieve recovery of

547 invertebrates to more normal communities. In the most severely affected lakes, with watersheds

548 that were also badly damaged, aquatic recovery will likely be closely linked to terrestrial 549 recovery. 
Foremost, continued monitoring of Sudbury area lakes will be essential to track future

553 changes and further develop our understanding of aquatic recovery processes amidst a variety of

554 concurrent local and regional environmental changes. Only by looking will we be able to see and

555 understand the changes that are happening in lakes. Studies in the Sudbury area have provided a

556 very clear demonstration of the necessity of comprehensive lake monitoring programmes to

557 evaluate the effectiveness of pollution control measures, and also to reveal the effects of other

558 new environmental stressors affecting aquatic ecosystems.

Monitoring programmes only have their greatest value when the necessary resources are

560 committed toward timely interpretation and reporting. To improve our current understanding of

561 biological recovery, increased effort needs to be devoted to updating analyses of temporal

562 patterns in the long-term zooplankton and phytoplankton datasets collected by the Sudbury lake

563 monitoring programmes. Long-term temporal patterns in thermal and oxygen regimes in these

564 lakes also need to be examined given the likely influence on thermal habitats and oxygen

565 distribution of large-scale changes such as climate warming and browning. As well, various past

566 studies of benthic macroinvertebrates, aquatic macrophytes and planktonic Chaoborus in

567 Sudbury area lakes can now provide a baseline from which the extent of recent community

568 change can be assessed. Future work should include repeat sampling of lakes with previous data

569 and assessments of temporal changes and current status.

Many questions remain about the future of Sudbury area lakes that need to be addressed

571 through ongoing research. We need to better understand the linkages between land and water

572 since these interactions will affect future lake recovery. Key aspects that need to be further

573 examined include determining the current magnitude of sulphur and metal storage in watersheds

574 and estimation of the timeframes that significant metal and acid inputs (long-term and episodic) 
575 to lakes are likely to continue. Estimation of current sediment recovery rates from metal 576 contamination would also be valuable since severe sediment metal contamination persists in 577 some lakes, affecting benthic macroinvertebrates. The extent to which increasing organic matter 578 from recovering terrestrial landscapes affects lake recovery also need to be further investigated. 579 The above studies would ideally include detailed process-oriented investigations, including field 580 surveys, paleolimnological studies, and experiments, on key lakes, and larger-scale empirical 581 assessments of relationships between lake recovery patterns and catchment characteristics across 582 a broad lake set using remote sensing and GIS tools. The above studies would greatly enhance 583 the ongoing Sudbury lake monitoring programmes, and lead to a much better understanding of 584 the patterns and processes of lake recovery in our multiple stressor world. This knowledge would 585 have great benefits, informing future lake management efforts in the Sudbury area and other 586 areas of the world affected by acid deposition.

588 Acknowledgements

Nels Conroy and Peter Dillon are gratefully acknowledged for having the vision and 590 determination to implement the original Sudbury lake monitoring programmes that still continue, 591 and in large measure have brought us to our present state of knowledge of Sudbury lake 592 recovery. Norman Yan has played a key role since the beginning, and the Sudbury aquatic 593 science programmes still benefit greatly from his wisdom and scientific acumen. John Smol and 594 the PEARL group at Queen's University have made invaluable contributions to Sudbury 595 recovery science by unravelling the history of many lakes from their sediment records. Shelley 596 Arnott and her numerous students at Queen's conducted many key field experiments, revealing 
597 important mechanisms involved in the biological recovery patterns that have been observed.

598 John Gunn and his students at Laurentian University have helped advance Sudbury limnology, 599 especially urban limnology. Ed Piche, Wolfgang Scheider and Rachael Fletcher made important 600 contributions to supporting and sustaining the Sudbury lake monitoring programmes over the 601 years. Vale and Glencore have provided valuable ongoing support for lake sampling. Two 602 journal referees provided very constructive reviews of the paper, substantially improving the 603 content and increasing the scope. Over almost five decades, hundreds of field staff, including 604 scientists, technicians and students, helped complete the sampling that ultimately created one of 605 the best lake datasets in the world.

606

607 References

608 Alofs, K.M., and Jackson, D.A. 2014. Meta-analysis suggests biotic resistance in freshwater 609 environments is driven by consumption rather than competition. Ecology, 95: 3259-3270.

610

Alofs, K.M., and Jackson, D.A. 2015. The vulnerability of species to range expansions by predators can be predicted using historical species associations and body size. Proc. R. Soc. B-Biol. Sci. 282: 20151211.

Alpay, S., Veillette, J.J., Dixit, A.S., and Dixit, S.S. 2006. Regional and historical distributions of lakewater $\mathrm{pH}$ within a 100-km radius of the Horne smelter in Rouyn-Noranda, Quebec, Canada. Geochem. Explor. Environ. Anal. 6: 179-186.

Arnott, S.E., and Yan, N.D. 2002. The influence of drought and re-acidification on zooplankton emergence from resting stages. Ecol. Appl. 12: 138-153. 
618 619

620

621

622

623

624

625

626

627

628

629

630

631

632

633

634

635

636

637

638

Arnott, S.E., Yan, N.D., Keller, W., and Nicholls, K. 2001. The influence of drought-induced acidification on the recovery of plankton in Swan Lake. Ecol. Appl. 11: 747-763.

Arnott, S.E., Dillon, P.J., Somers, K.M., and Keller, W. 2003a. Inter- and intra-annual chemical variability during the ice-free season in lakes with different flushing rates and acid deposition histories. Environ. Monit. Assess. 88 :21-37.

Arnott, S.E., Keller, W., Dillon, P.J., Yan, N.D., Paterson, M., and Findlay, D. 2003b. Using temporal coherence to determine the response to climate change in Boreal Shield lakes. Environ. Monit. Assess. 88 :365-368.

Arnott, S.E., Jackson, A.B., and Alarie, Y. 2006. Distribution and potential effects of water beetles in lakes recovering from acidification. J. N. Am. Benthol. Soc. 25: 811-824.

Ashforth, D., and Yan, N.D. 2008. The interactive effects of calcium concentration and temperature on the survival and reproduction of Daphnia pulex at high and low food concentrations. Limnol. Oceanogr. 53(2): 420-432.

Audet, C., MacPhee, S., and Keller, W. 2013. Constructed ponds colonized by crustacean zooplankton: local and regional influences. J. Limnol. 72: 524-530. DOI: 10.4081/jlimnol. 2013.e43.

Azan, S.S.E., and Arnott, S.E. 2017. The impact of calcium decline on population growth rates of crustacean zooplankton in Canadian Shield lakes. Limnol. Oceanogr. 63: 602-616.

Babin-Fenske, J.J., Merritt, T.J.S., Gunn, J.M., Walsh, T., and Lesbarrere, D. 2012. Phylogenetic analysis of Hyalella colonization in lakes recovering from acidification and metal contamination. Can. J. Zool. 90: 624-629. 
Balistrieri, L.S., Mebane, C.A., Schmidt, T.S., and Keller, W. 2015. Expanding metal mixture acute toxicity models to natural stream and lake invertebrate communities. Environ. Toxicol. Chem. 34: 761-776.

Bates, R., Maechler, M., Bolker, B., and Walker, S. 2017. Package 'lme4': Linear MixedEffects. https://cran.r- project.org/web/packages.lme/lme1/lme4.pdf.

Beamish, R.J. 1974. Loss of fish populations from unexploited remote lakes in Ontario, Canada, as a consequence of atmospheric fallout of acid. Water Res. 8: 85-95.

Beamish, R.J., and Harvey, H.H. 1972. Acidification of the LaCloche Mountain lakes, Ontario, and resulting fish mortalities. J. Fish. Res. Board Can. 29: 1131-1143.

Beamish, R.J., Lockhart, W.L., van Loon, J.C., and Harvey, H.H. 1975. Long term acidification of a lake and resulting effects on fishes. Ambio, 4: 98-102.

Belzile, N., and Morris, J.R. 1995. Lake sediments: sources or sinks of industrially mobilized elements. In Restoration and recovery of an industrial region. Edited by J.M. Gunn. Springer Verlag. pp. 183-193.

Bergeron, J.M. 2012. Urban and industrial drivers of phytoplankton communities in Sudbury, Ontario, urban lakes. M. Sc. Thesis, Laurentian University, Sudbury, Ontario, Canada, 197 p.

Binks, J.A., Arnott, S.E., and Sprules, W.G. 2005. Local factors and colonist dispersal influence crustacean zooplankton recovery from cultural acidification. Ecol. Appl. 15: 2025-2036.

Borgmann, U. 2003. Derivation of cause-effect based sediment quality guidelines. Can. J. Fish. Aquat. Sci. 60: 352-360. 
660 661

662

663

664

665

666

667

668

669

670

671

672

673

674

675

676

677

678

679

680

681

Borgmann, U., Jackson, T.A., Reynoldson, T.B., and Rosa, F. 1998. Interim report on the effects of atmospheric deposition of metals from the Sudbury smelters on aquatic benthic ecosystems. National Water Research Institute Rep. 98-230. Burlington, Ontario, 148p.

Cairns, A., and Yan, N.D. 2009. A review of the influence of low ambient calcium concentrations on freshwater daphniids, gammarids, and crayfish. Environ. Rev. 17: 67-79.

Carbone, J., Keller, W., and Griffiths, R.W. 1998. Effects of changes in acidity on aquatic insects in rocky littoral habitats of lakes near Sudbury, Ontario. Restor. Ecol. 6: 376-389.

Casselman, J.M., and Gunn, J.M. 1992. Dynamics in year-class strength, growth, and calcifiedstructure size of native lake trout (Salvelinus namaycush) exposed to moderate acidification and whole-lake neutralization. Can. J. Fish. Aquat. Sci. 49(Suppl. 1): 102-113.

Celis-Salgado, M.P., Keller, W., and Yan, N.D. 2016. Calcium and sodium as regulators of the recovery of four Daphnia species along a gradient of metals and base cations in contaminated lakes in Sudbury, Ontario, Canada. J. Limnol. 75(s2): 36-49.

Cloran, C.E., Burton, G.A., Hammerschmidt, C.R., Taulbee, W.K., Custer, K.W., and Bowman, K.L. 2010. Effects of suspended solids and dissolved organic carbon on nickel toxicity. Environ. Toxicol. Chem. 29: 1781-1787.

Conroy, N.I., and Keller, W. 1976. Geological factors affecting biological activity in Precambrian Shield lakes. Can. Mineral. 14: 62-72.

Conroy, N.I., Jeffries, D.S., and Kramer, J.R. 1974. Acid shield lakes in the Sudbury, Ontario, region. Proc. Water Pollut. Res. Can. 9: 45-61.

Conroy, N.I., Hawley, K., Keller, W., and Lafrance, C. 1976. Influences of the atmosphere on lakes in the Sudbury area. J. Great Lakes Res. 2(Suppl. 1): 146-165. 
682 Conroy, N.I., Hawley, K., and Keller, W. 1978. Extensive monitoring of lakes in the greater

683

684

685

686

687

688

689

690

691

692

693

694

695

696

697

698

699

700

701

Sudbury area, 1974-76. Ontario Ministry of the Environment Rept., Sudbury Ontario. 40 p, plus appendices.

Cuss, C.W., Guegen, C., Hill, E., and Dillon, P.J. 2010. Spatio-temporal variation of the characteristics of dissolved organic matter in streams of boreal forests: impacts on modelled copper speciation. Chemosphere, 80: 764-770.

Derry, A.M., and Arnott, S.E. 2007. Zooplankton community response to experimental acidification in Boreal Shield lakes with different ecological histories. Can. J. Fish. Aquat. Sci. 64: 887898.

Dillon, P.J., Yan, N.D., Scheider, W.A., and Conroy, N. 1979. Acidic lakes in Ontario, Canada: characterization, extent, and responses to base and nutrient additions. Arch. Hydrobiol. Beih. 13: 317-336.

Dillon, P.J., Reid, R.A., and Girard, R. 1986. Changes in the chemistry of lakes near Sudbury, Ontario, following reductions of $\mathrm{SO}_{2}$ emissions. Water Air Soil Pollut. 31: 59-65.

Dixit, S.S., Dixit, A.S., and Evans, R.D. 1988. Scaled chrysophytes (Chrysophyceae) as indicators of pH in Sudbury, Ontario, lakes. Can. J. Fish. Aquat. Sci. 45: 1411-1421.

Dixit, S.S., Dixit, A.S., and Smol, J.P. 1989. Lake acidification recovery can be monitored using chrysophycean microfossils. Can. J. Fish. Aquat. Sci. 46: 1309-1312.

Dixit, S.S., Dixit, A.S., and Smol, J.P. 1992a. Assessment of changes in lakewater chemistry in Sudbury area lakes since preindustrial times. Can. J. Fish. Aquat. Sci. 49(Suppl. 1): 8-16. 
702 Dixit, S.S., Dixit, A.S., and Smol, J.P. 1992b. Long term trends in lake water pH and metal 703 704

705 706

707

708

709

710

711 concentrations inferred from diatoms and chrysophytes in three lakes near Sudbury, Ontario. Can. J. Fish. Aquat. Sci. 49(Suppl. 1): 17-24.

Dixit, S.S., Dixit, A.S., and Smol, J.P. 1993. Acidification and metal contamination in Whitepine Lake (Sudbury, Canada): a paleolimnological perspective. J. Paleolimnol. 9: 141-146.

Dixit, S.S., Dixit, A.S., Smol, J.P., and Keller, W. 1995. Reading the records stored in the lake sediments: a method of examining the history and extent of industrial damage to lakes. In Restoration and recovery of an industrial region. Edited by J.M. Gunn. Springer Verlag. pp. $33-44$.

Dixit, S.S., Dixit, A.S., and Smol, J.P. 1996. Long-term trends in limnological characteristics in the aurora trout lakes, Sudbury, Canada. Hydrobiologia, 335: 171-181.

Dixit, S.S., Keller, W., Dixit, A.S., and Smol, J. 2001. Diatom-inferred dissolved organic carbon reconstructions provide assessments of past UV-B penetration in Canadian Shield lakes. Can. J. Fish. Aquat. Sci. 58: 543-550.

Dodge, D.P., Booth, G.M., Richman, L.A., Keller, W., and Tomassini, F.D. 1988. An overview of lake neutralization experiments in Ontario, 1981-1987. Water Air Soil Pollut. 41 (1-4): 75-84.

Edwards, B.A., Jackson, D.A., and Somers, K.M. 2009. Multi-species crayfish declines in lakes: implications for species distributions and richness. J. N. Am. Benthol. Soc. 28: 719-732. 
721 Edwards, B.A., Jackson, D.A., and Somers, K.M. 2015. Evaluating the effect of lake calcium

722

723

724

725

726

727

728

729

730

731

732

733

734

735

736

737

738

739

740

741

concentration on the acquisition of carapace calcium by freshwater crayfish. Hydrobiologia, 744: 91-100.

Edwards, B.A., Southee, F.M., and McDermid, J.L. 2016. Using climate and a minimum set of local characteristics to predict the future distributions of freshwater fish in Ontario, Canada, at the lake-scale. Glob. Ecol. Conserv. 8: 71-84.

Eimers, C., Watmough, S.A., Paterson, A.M., Dillon, P.J., and Yao, H. 2009. Long-term declines in phosphorus export from forested catchments in south-central Ontario. Can. J. Fish. Aquat. Sci. 66: 1682-1692.

Findlay, D.L. 2003. Response of phytoplankton communities to acidification and recovery in Killarney Park and the Experimental Lakes Area, Ontario. Ambio, 32(3): 190-195.

Garmo, Ø.A., Skjelkvale, B.L., de Wit, H.E., Colombo, L., Curtis, C., Folster, J., Hoffmann, A., Hogasen, T., Jeffries, D., Keller, W., Majer, V., Paterson, A., Rogora, M., Rzychon, D., Steingruber, A., Stoddard, J.L., Vuorenmaa, J., and Worsztynowicz, A. 2014. Trends in surface water chemistry in acidified areas in Europe and North America from 1990 to 2008. Water Air Soil Pollut. 225: 1880 DOI 10.1007/s11270-014-1880-6.

Gorham, E., and Gordon, A.G. 1960. The influence of smelter fumes upon the chemical composition of lake waters near Sudbury, Ontario and upon the surrounding vegetation. Can. J. Bot. 38: 477-487.

Graham, M.D., Vinebrooke, R.D., Keller, W., Heneberry, J., Nicholls, K.H., and Findlay, D.L. 2007. Comparative responses of phytoplankton during chemical recovery in atmospherically 
and experimentally acidified lakes. J. Phycol. 43: 908-923. DOI: 10.1111/j.152917.2007.00398.x.

Gray, D.K., and Arnott, S.E. 2009. Recovery of acid-damaged zooplankton communities: measurement, extent and limiting factors. Environ. Rev. 17: 81-99.

Gray, D.K., and Arnott, S.E. 2011. Does dispersal limitation impact the recovery of zooplankton damaged by a regional stressor? Ecol. Appl. 21(4): 1241-1246.

Gray, D.K., Arnott, S.E., Shead, J.A., and Derry, A.M. 2012. The recovery of acid-damaged zooplankton communities in Canadian lakes: the relative importance of abiotic, biotic and spatial variables. Freshwater Biol. 57: 741-758.

Griffiths, R.W., and Keller, W. 1992. Benthic macroinvertebrate changes in lakes near Sudbury, Ontario, following a reduction in acidity. Can. J. Fish. Aquat. Sci. 49(Suppl. 1): 63-75.

Gunn, J.M. and Keller, W. 1990. Biological recovery of an acid lake after reductions in industrial emissions of sulphur. Nature, 345: 431-433.

Gunn, J.M., and Keller, W. 1995. Urban lakes: integrators of environmental damage and recovery. In Restoration and recovery of an industrial region. Edited by J.M. Gunn. Springer Verlag. pp. 257-269.

Gunn, J.M., and Sandoy, S. 2003. Introduction to the Ambio special issue on biological recovery from lake acidification: Northern Lakes Recovery Study. Ambio, 32: 162-164.

Gunn, J.M., McMurty, M.J., Casselman, J.M., Keller, W., and Powell, M.J. 1988. Changes in the fish community of a limed lake near Sudbury, Ontario: effects of chemical neutralization or reduced atmospheric deposition of acids? Water Air Soil Pollut. 41: 113-136. 
Gunn, J.M., Hamilton, J.G., Booth, G.M., Wren, C.D. , Beggs, G.L., Rietveld, H.J., and Munro, J.R. 1990. Survival, growth, and reproduction of lake trout (Salvelinus namaycush) and yellow perch (Perca flavescens) after neutralization of an acidic lake near Sudbury, Ontario. Can. J. Fish. Aquat. Sci. 47: 446-453.

Gunn, J.M., Sein, R., Keller, W., and Beckett, P. 2001. Liming acid of and metal contaminated catchments for the improvement of drainage water quality. Water Air Soil. Pollut. 130: $1439-1444$.

Gunn, J.M., Szkokan-Emilson, E., and Kielstra, B.W. 2016. Catchment liming creates colonization opportunity for sensitive invertebrates in a smelter impacted landscape. J. Limnol. 75(s2): 50-58.

Havas, M., Woodfine, D.G., Lutz, P., Yung, K., MacIsaac, H.J., and Huchinson, T.C. 1995. Biological recovery of two previously acidified, metal-contaminated lakes near Sudbury, Ontario, Canada. Water Air Soil Pollut. 85: 791-796.

Havens, K.E., Yan, N.D., and Keller, W. 1993. Lake acidification: effects on crustacean zooplankton populations. Environ. Sci. Technol. 27:1621-1624.

Helmus, M.R., Keller, W., Paterson, M.J., Yan, N.D., Cannon, C.H., and Rusak, J.A. 2010. Communities contain closely related communities during ecosystem disturbance. Ecology Letters, 13: 162-174.

Heneberry, J. 1997. Absence of large grazers: an obstacle to recovery in acid and metal damaged lakes. M. Sc. Thesis, Laurentian University, Sudbury, Ontario, Canada, 108 p. 
784 Henrikson, L., and Brodin, Y.W. (Editors). 1995. Liming of acidified surface waters, a Swedish 785 synthesis. Springer-Verlag, New York, Berlin, Heidelberg.

786

787

788

789

790

791

792

793

794

795

796

797

798

799

800

801

802

803

Hessen, D.O., and Alstad Rukke, N. 2000. UV radiation and low calcium as mutual stressors for Daphnia. Limnol. Oceanogr. 45: 1834-1838.

Holt, C., and Yan, N.D. 2003. Recovery of zooplankton from acidification in Killarney Park, Ontario, 1971-2000: pH 6 as a recovery goal. Ambio, 32: 203-207.

Hutchinson, T.C., and Havas, M. 1986. Recovery of previously acidified lakes near Coniston, Canada, following reductions in atmospheric sulphur and metal emissions. Water Air Soil Pollut. 28: 319-333.

Jackson, M.B., and Vandermeer, E.M. 1990. Effects of neutralization and early re-acidification on filamentous algae and macrophytes in Bowland Lake. Can. J. Fish. Aquat. Sci. 47: 432-439.

Jeffries, D.S., Brydges, T.G., Dillon, P.J., and Keller, W. 2003. Monitoring the results of Canada/U.S.A. acid rain control programmes: some lake responses. Environ. Monit. Assess. 88: 3-19.

Jeziorski, A., and Smol, J.P. 2017. The ecological impacts of lakewater calcium decline on softwater boreal ecosystems. Environ. Rev. 25: 245-253.

Jeziorski, A., Yan, N.D., Paterson, A.M., DeSellas, A.M., Turner, M.A., Jeffries, D.S., Keller, W., Weeber, R.C., McNicol, D.K., Palmer, M.E., McIver, K., Arseneau, K., Ginn, B.K., Cumming, B.F., and Smol, J.P. 2008. The widespread threat of calcium decline in freshwaters. Science, 322: 374-1377. DOI 10.1126 Science 1164949. 
804

805

806

807

808

809

810

811

812

813

814

815

816

817

818

819

820

821

822

823

824

Jeziorski, A., Keller, B., Paterson, A.M., Greenaway, C.N., and Smol, J.P. 2013. Aquatic ecosystem responses to rapid recovery from extreme acidification and metal contamination in lakes near Wawa, Ontario. Ecosystems, 16: 209-223.

Jeziorski, A., Tanentzap, A.J., Yan, N.D., Paterson, A.M., Palmer, M.E., Korosi, J.B., Rusak, J., Arts, M., Keller, W., Ingram, R., and Smol, J.P. 2014. The jellification of north temperate lakes. Proc. Roy. Soc. B-Biol. Sci. 282: 20142449.

Kappes, H., and Haase, P. 2012. Slow, but steady: dispersal of freshwater molluscs. Aquat. Sci. 74: 1-14.

Keller, W. 1978. Limnological observations on the aurora trout lakes. Ontario Ministry of the Environment Rept., Sudbury, Ontario, 48 p.

Keller, W. 1992. Introduction and overview to aquatic acidification studies in the Sudbury, Ontario, Canada area. Can. J. Fish. Aquat. Sci. 49(Suppl. 1): 3-7.

Keller, W. 2007. Implications of climate warming for Boreal Shield lakes: a review and synthesis. Environ. Rev. 5: 99-112.doi:10.1139/A07-002.

Keller, W. 2009. Limnology in northeastern Ontario: from acidification to multiple stressors. Can. J. Fish. Aquat. Sci. 66: 1189-1198.

Keller. W., and Gunn, J.M. 1995. Lake water quality improvements and recovering aquatic communities. In Restoration and recovery of an industrial region. Edited by J.M. Gunn. Springer Verlag. pp. 67-80.

Keller, W., and Pitblado, J.R. 1984. Crustacean plankton in northeastern Ontario lakes subjected to acidic deposition. Water Air Soil Pollut. 23: 271-291. 
825 Keller, W., and Pitblado, J.R. 1986. Water quality changes in Sudbury area lakes: a comparison 826 of synoptic surveys in 1974-76 and 1981-83. Water Air Soil Pollut. 29: 285-296.

827 Keller, W., and Yan, N.D. 1991. Recovery of crustacean zooplankton species richness in Sudbury 828

829 830 831 area lakes following water quality improvements. Can. J. Fish. Aquat. Sci. 48: 1635-1644.

Keller, W., and Yan, N.D. 1998. Biological recovery from lake acidification: zooplankton communities as a model of patterns and processes. Restor. Ecol. 6: 364-375.

Keller, W., Gunn, J., and Conroy, N. 1980. Acidification impacts on lakes in the Sudbury, Ontario, Canada area. In Proc. Int. Conf. on the Ecological Impact of Acid Precipitation, Sandefjord, Norway, Edited by D. Drablos and A. Tollan. pp. 228-229.

Keller, W., Pitblado, J.R., and Conroy, N.I. 1986. Water quality changes in the Sudbury, Ontario, Canada area related to reduced smelter emissions. Water Air Soil Pollut. 31: $765-774$

Keller, W., Yan, N.D., Holtze, K., and Pitblado, J.R. 1990a. Inferred effects of lake acidification on Daphnia galeata mendotae. Environ. Sci. Technol. 24: 1259-1261.

Keller, W., Molot, L.A., Griffiths, R.W., and Yan, N.D. 1990b. Changes in the zoobenthos community of acidified Bowland Lake after whole-lake neutralization and lake trout (Salvelinus namaycush) reintroduction. Can. J. Fish. Aquat. Sci. 47: 440-445.

Keller, W., Dodge, D.P., and Booth, G.M. 1990c. Experimental lake neutralization program: Overview of studies in Ontario. Can. J. Fish. Aquat. Sci. 47: 410-411. 
844 Keller, W., Pitblado, J.R., and Carbone, J. 1992a. Chemical responses of acidic lakes in the

845

846

847

848

849

850

851

852

853

854

855

856

857

858

859

860

861

862

863

864 Sudbury, Ontario area to reduced smelter emissions, 1981 to 1989. Can. J. Fish. Aquat. Sci. 49(Suppl. 1): 25-32.

Keller, W., Gunn, J.M., and Yan, N.D. 1992b. Evidence of biological recovery in acid stressed lakes near Sudbury, Canada. Environ. Pollut. 78: 79-85.

Keller, W., Yan, N.D., Howell, T., Molot, L.A., and Taylor, W.D. 1992c. Changes in zooplankton during the experimental neutralization and early re-acidification of Bowland Lake near Sudbury, Ontario. Can. J. Fish. Aquat. Sci. 49(Suppl. 1): 52-62.

Keller, W., Gunn, J., and Yan, N. 1999a. Acid rain: perspectives on lake recovery. J. Aquat. Ecosys. Stress Recovery, 6: 207-216.

Keller, W., Heneberry, J., and Gunn, J. 1999b. Effects of emission reductions from the Sudbury smelters on the recovery of acid and metal-damaged lakes. J. Aquat. Ecosys. Stress Recovery, 6: 189-198.

Keller, W., Heneberry, J., Clark, M., Malette, M., and Gunn, J.M. 1999c. Effects of emission reduction from the smelters in Sudbury on recovery of lakes within the metal deposition zone. In Proc. Mining and the Environment II, Sudbury, Ontario. Edited by D. Goldsack, N. Belzile, P. Yearwood, and G. Hall. pp. 483-492.

Keller, W., Dillon, P.J., Heneberry, J., Malette, M., and Gunn, J. 2001a. Sulphate in Sudbury, Ontario, Canada lakes: recent trends and status. Water Air Soil Pollut. 130: 793-798.

Keller, W., Dixit, S.S., and Heneberry, J. 2001b. Calcium declines in northeastern Ontario lakes. Can. J. Fish. Aquat. Sci. 58: 2011-2020. 
865 Keller, W., Yan, N.D., Somers, K.M., and Heneberry, J.H. 2002. Crustacean zooplankton 866 communities in lakes recovering from acidification. Can. J. Fish. Aquat. Sci. 59: 726-735.

867 Keller, W., Heneberry, J.H., and Dixit, S.S. 2003. Decreased acid deposition and the chemical 868 recovery of Killarney, Ontario, lakes. Ambio, 32: 183-189.

869

870

871

872 873

874

875

876

877

878

879 880

881

882

883

Keller, W., Heneberry, J., Gunn, J., Snucins, E., Morgan, G., and Leduc, J. 2004. Recovery of acid and metal-damaged lakes near Sudbury Ontario: trends and status. Cooperative Freshwater Ecology Unit Tech. Rept. Laurentian University, Sudbury, Ontario. 53 p.

Keller, W., Heneberry, J., and Leduc, J. 2005. Linkages between weather, dissolved organic carbon, and coldwater habitat in a Boreal Shield lake recovering from acidification. Can. J. Fish. Aquat. Sci. 62: 340-346.

Keller, W., Heneberry, J., Leduc, J., Gunn, J., and Yan, N.D. 2006. Variations in epilimnion thickness in small Boreal Shield lakes: relationships with transparency, weather and acidification. Environ. Monit. Assess. 115: 419-431.

Keller, W., Yan, N.D., Gunn, J.M., and Heneberry, J. 2007. Recovery of acidified lakes: lessons from Sudbury, Ontario, Canada. Water Air Soil Pollut. Focus, 7: 317-322. DOI 10.1007/s11267-006-9061-2.

Keller, W., Paterson, A., Somers, K., Dillon, P., Heneberry, J., and Ford, A. 2008. Relationships between dissolved organic carbon concentrations, weather, and acidification in small Boreal Shield lakes. Can. J. Fish. Aquat. Sci. 65: 786-795. 
884 Khan, F.R., Keller, W., Yan, N.D., Welsh, P.G., Wood, C.M., and McGeer, J.C. 2011. Application

885

886

887

888

889

890

891

892

893

894

895

896

897

898

899

900

901

902 of biotic ligand and toxic unit modeling approaches to predict improvement in species richness in smelter damaged lakes near Sudbury. Environ. Sci. Technol. 46: 1641-1649.

Kielstra, B.W., Arnott, S.E., and Gunn, J.M. 2017. Subcatchment deltas and upland features influence multiscale aquatic ecosystem recovery in damaged landscapes. Ecol. Appl. 27: 2249-2261.

Kwiatkowksi, R.E., and Roff, J.C. 1976. Effects of acidity on the phytoplankton and primary productivity of selected northern Ontario lakes. Can. J. Bot. 54: 2546-2561.

Labaj, A.L., Kurek, J., Jeziorski, A., and Smol, J.P. 2015. Elevated metal concentrations inhibit biological recovery of Cladocera in previously acidified boreal lakes. Freshwater Biol. 60: $347-359$.

Labaj, A.L., Korosi, J.B., Kurek, J., Jeziorski, A., Keller, W., and Smol, J.P. 2016. The responses of Bosmina size structure to the acidification and subsequent recovery of lakes near Sudbury, Canada. J. Limnol. 75(s2): 22-29.

Lamothe, K.A., Jackson, D.A., and Somers, K.M. 2018. Long-term directional trajectories among lake crustacean zooplankton communities and water chemistry. Can. J. Fish. Aquat. Sci. doi.org/10.1139/cjfas-2017-0518.

Larssen, T., Brereton, C., and Gunn, J.M. 2003. Dynamic modelling of recovery from acidification of lakes in Killarney Park, Ontario, Canada. Ambio, 32: 244-248. 
903 904 905 906 907

908 909 910 911

Lautenbach, W.E., Miller, J., Beckett, P.J., Negusanti, J.J., and Winterhalder, K. 1995. Municipal land restoration program: the regreening process. In Restoration and recovery of an industrial region. Edited by J.M. Gunn. Springer Verlag. pp. 109-122.

Locke, A., Sprules, W.G., Keller, W., and Pitblado, J.R. 1994. Zooplankton communities and water chemistry of Sudbury area lakes: changes related to $\mathrm{pH}$ recovery. Can. J. Fish. Aquat. Sci. 51: 151-160.

Luek, A., Morgan, G.E., Whissel, B., Gunn, J.M., and Ramcharan, C.W. 2010. Rapid and unexpected effects of piscivore introduction on trophic position and diet of perch (Perca flavescens) in lakes recovering from acidification and metal contamination. Freshwater Biol. 55(8): 1616-1627.

Luek, A., Morgan, G.E., Wissel, B., Gunn, J.M., and Ramcharan, C.W. 2013. Impaired littoral energy pathways cause a shift to pelagic resources by fish in recovering lakes food webs. Ecol. Freshw. Fish, 22(3): 348-360.

Luek, A., Morgan, G.E., and Ramcharan, C.W. 2015. Biomass of benthic invertebrates unaffected by industrial damage to lakes despite effects on species composition. Hydrobiologia, 744: 101-114.

MacIsaac, H.J., Keller, W., Hutchinson, T.C., and Yan, N.D. 1986. Natural changes in the planktonic rotifera of a small acid lake near Sudbury, Ontario following water quality improvements. Water Air Soil Pollut. 31: 791-797. 
922 MacIsaac, H.J., Hutchinson, T.C., and Keller, W. 1987. An analysis of planktonic rotifer

923

924

925

926

927

928

929

930

931

932

933

934

935

936

937

938

939

940

941

942 assemblages from Sudbury, Ontario lakes of varying chemical composition. Can. J. Fish. Aquat. Sci. 44: 1692-1701.

MacPhee, S., Arnott, S., and Keller, W. 2011. Lake thermal structure influences macroinvertebrate predation on crustacean zooplankton. J. Plankton Res. 33: 1586-1595.

Manca, M.M., Bonacina, C., and Yan, N.D. 2016. What have we learned about ecological recovery from liming interventions of acid lakes in Canada and Italy? J. Limnol. 75(s2):1-3.

Matuszek, J.E., Wales, D.L., and Gunn, J.M. 1992. Estimated impacts of $\mathrm{SO}_{2}$ emissions from Sudbury smelters on Ontario`s sportfish populations. Can. J. Fish. Aquat. Sci. 49 (Suppl. 1): $87-94$.

MOEE (Ministry of the Environment and Energy). 1993. Guidelines for the protection and management of aquatic sediment quality in Ontario. Ontario Ministry of the Environment and Energy Rept. Toronto, Ontario. 24 p.

MOEE (Ministry of the Environment and Energy). 1994. Water management policies, guidelines, provincial water quality objectives. Ontario Ministry of the Environment and Energy Rept. Toronto, Ontario. 31 p.

Moiseenko, T. 1994. Acidification and critical loads in surface waters: Kola, northern Russia. Ambio, 23: 418-424.

Molot, L.A., Dillon, P.J., and Booth, G.M. 1990a. Whole-lake and nearshore water chemistry in Bowland Lake before and after treatment with $\mathrm{CaCO}_{3}$. Can. J. Fish. Aquat. Sci. 47: 412421. 
943 944 945 946 947 948 949 950 951 952 953 954 955 956 957 958 959 960 961

Molot, L.A., Heintsch, L., and Nicholls, K.H. 1990b. Response of phytoplankton in acidic lakes in Ontario to whole lake neutralization. Can. J. Fish. Aquat. Sci. 47: 422-431.

Molot, L.A., Keller, W., Leavitt, P.R. , Robarts, R.D., Waiser, M.J., Arts, M.T., Clair, T.A., Pienitz, R., Yan, N.D., McNicol, D., Prairie, Y., Dillon, P.J., Macrae, M., Bello, R., Nordin, R., Curtis, P.J., Smol, J.P., and Douglas, M. 2004. Risk analysis of dissolved organic mattermediated ultraviolet B exposure in Canadian inland waters. Can. J. Fish. Aquat. Sci. 61: 2511-2521.

Monteith, D.T, Stoddard, J.L., Evans, C.D., de Wit, H.A., Forsius, M., Hogasen, T., Wilander, A., Skjelkvale, B.L., Jeffries, D.S., Vuorenmaa, J., Keller, B., Kopacek, J., and Vesely, J. 2007. Dissolved organic carbon trends resulting from changes in atmospheric deposition chemistry. Nature, 450: 537-541. doi: 10.1038/nature06316.

Neary, B.P., Dillon, P.J., Munro, J.R., and Clark, B. 1990. The acidification of Ontario lakes: an assessment of their sensitivity with respect to biological damage. Ontario Ministry of the Environment, Dorset, Ontario, Tech. Rept. 170 p.

Nicholls, K.H., Nakamoto, L., and Keller, W. 1992. The phytoplankton of Sudbury area lakes (Ontario) and relationships with acidification status. Can. J. Fish. Aquat. Sci. 49(Suppl. 1): $40-51$.

Nriagu, J.O., Wong, H.K.T., Lawson, G., and Cook, R.D. 1998. Saturation of ecosystems with toxic metals in Sudbury Basin Ontario. Sci. Total Environ. 223: 99-117. 
Olem, H., Schreiber, R.K., Brocksen, R.W., and Porcella, D.B. (Editors). 1991. International lake and watershed liming practices. The Terrene Institute, Washington, D.C. ISBN 1-88068600-7.

OWRC (Ontario Water Resources Commission). 1970. Preliminary report on the influence of industrial activity on the lakes in the Sudbury area, 1969-1970. Ontario Water Resources Commision Report, Toronto, Ontario, 34 p. plus appendices.

Pagnucco, K., Maynard, G.A., Fera, S.A., Yan, N.D., Nalepa, T.F., and Ricciardi, L.A. 2015. The future of species invasions in the Great Lakes - St. Lawrence River basin. J. Great Lakes Res. 41(Suppl. 1): 96-107.

Palmer M.E., and Yan, N.D. 2013. Decadal-scale regional changes in Canadian freshwater zooplankton: the likely consequence of complex interactions among multiple anthropogenic stressors. Freshwater Biol. 58(7): 1366-1378.

Palmer M.E., Yan, N.D., Paterson, A.M., and Girard, R.E. 2011. Water quality changes in southcentral Ontario lakes and the role of local factors in regulating lake response to regional factors. Can. J. Fish. Aquat. Sci. 68: 1038-1050.

Palmer, M.E., Keller, W., and Yan, N.D. 2013. Reassessing the recovery of crustacean zooplankton communities in historically acidified and metal-contaminated lakes: a comparative analysis of the temporal limitations of regional restoration targets. J. Appl. Ecol. 50: 107-118.

Park, E.J., Jo, H.J., and Jung, J. 2009. Combined effects of pH, hardness and dissolved organic carbon on acute metal toxicity to Daphnia magna. Jour. Industr. Eng. Chem. 15: 82-85. 
982 Paterson, A.M., Winter, J.G., Nicholls, K.H., Clark, B.J., Ramcharan, C.W., Yan, N.D., and 983 Somers, K.M. 2008. Long-term changes in phytoplankton composition in seven Canadian Shield lakes in response to multiple stressors. Can. J. Fish. Aquat. Sci. 65(5): 846-861.

985 986

987

988 989 990 991 992 993 994 995 996 997 998 999 1000

Pearson, D., Gunn, J. M., and Keller, W. 2002. The past, present, and future of Sudbury's lakes. In Physical environment of the Sudbury region. Edited by D.H. Rousell and K. Janson's. Geological Survey Special Volume. Sudbury, Ontario. pp. 195-215.

Persaud, A.D., and Yan, N.D. 2003. UVR sensitivity of Chaoborus larvae. Ambio, 32: 219-224.

Pitblado, J.R., and Keller, W. 1984. Data report - Monitoring of northeastern Ontario lakes, 19811983. Ontario Ministry of the Environment and Energy Rept. Sudbury, Ontario. 9 p, plus appendices.

Pollard, H.G., Colbourne, J., and Keller, W. 2003. Reconstruction of centuries old Daphnia communities in a lake recovering from acidification and metal-contamination. Ambio, 32: 214-218.

Potvin, R., and Negusanti, J. 1995. Declining industrial emissions, improving air quality, and reduced damage to vegetation. In Restoration and recovery of an industrial region. Edited by J.M. Gunn. Springer Verlag. pp. 51-65.

Reasbeck, J.A. 1997. Changes in benthic macroinvertebrate community structure in acid and metal contaminated lakes following water quality improvements. M. Sc. Thesis, Laurentian University, Sudbury, Ontario, Canada, 95 p. 
1001

1002

1003

1004

1005

1006

1007

1008

1009

1010

1011

1012

1013

1014

1015

1016

1017

1018

1019

1020

1021

Riessen, H.P., Linley, R.D., Altshuler, M., Rabus, M., Söllradl, T., Clausen-Schaumann, H., Laforsch, C., and Yan, N.D. 2012. Changes in water chemistry can disable plankton prery defenses. Proc. Nat. Acad. Sci. 109: 15377-15382.

Roff, J.C., and Kwiatkowski, R.E. 1977. Zooplankton and zoobenthos communities of selected northern Ontario lakes of different acidities. Can. J. Zool. 55: 899-911.

Semkin, R.G., and Kramer, J.R. 1976. Sediment geochemistry of Sudbury-area lakes. Can. Mineral. 14: 73-90.

Shurin, J.B., Winder, M., Adrian, R., Keller, W., Matthews, B., Paterson, A.M., Paterson, M., Pinel-Alloul, B., Rusak, J.A., and Yan, N.D. 2010. Environmental stability and lake zooplankton diversity - contrasting effects of chemical and thermal variability. Ecology Letters, 13: 453-463.

Sivarajah, B., Rühland, K.M., Labaj, A.L., Paterson, A.M., and Smol, J.P. 2016. Why is the relative abundance of Asterionella formosa increasing in a Boreal Shield lake as nutrient levels decline? J. Paleolimnol. 55: 357-367.

Sivarajah, B., Rühland, K.M., and Smol, J.P. 2017. Are diatoms recovering to pre-acidification assemblages in a warming world? Revisiting Killarney Provincial Park lakes (Ontario, Canada). Fund. Appl. Limnol. 190: 13-28. DOI: 10.1127/fal/2017/o981.

Skeffington, R.A., and Brown, D.J.A. 1992. Timescales of recovery from acidification: implications of current knowledge for aquatic organisms. Environ. Pollut. 77: 227-234.

Smol, J.P., Cumming, B.F., Dixit, A.S., and Dixit, S.S. 1998. Tracking recovery patterns in acidified lakes: a paleolimnological perspective. Restor. Ecol. 6: 318-326. 
1022

1023

1024

1025

1026

1027

1028

1029

1030

1031

1032

1033

1034

1035

1036

1037

1038

1039

1040

1041

Snucins, E.J. 2003. Recolonization of acid-damaged lakes by the benthic invertebrates Stenacron interpunctatum, Stenonema femoratum, and Hyalella azteca. Ambio, 32: 225-229.

Snucins, E.J., and Gunn, J.M. 2000. Interannual variation in the thermal structure of clear and colored lakes. Limnol. Oceanogr. 45: 1639-1646.

Snucins, E.J., and Gunn, J.M. 2003. Use of rehabilitation experiments to understand the recovery dynamics of acid-stressed fish populations. Ambio, 32: 240-243.

Snucins. E.J., Gunn, J.M., and Keller, W. 1995a. Restoration of the aurora trout to its acid-damaged native habitat. Conserv. Biol. 9: 1307-1311.

Snucins. E.J., Gunn, J.M., and Keller, W. 1995b. Preservation of Biodiversity: Aurora Trout. In Restoration and recovery of an industrial region. Edited by J.M. Gunn. Springer Verlag. pp. 143-153.

Sprules.W.G. 1975. Midsummer crustacean zooplankton communities in acid-stressed lakes. J. Fish. Res. Board Can. 32: 389-385.

Sprules, W.G. 1977. Crustacean zooplankton communities as indicators of limnological conditions: an approach using principal component analysis. J. Fish. Res. Board Can. 34: 962-974.

Stephenson, M., and Mackie, G.L. 1986. Lake acidification as a factor in the distribution of the freshwater amphipod Hyalella azteca. Can. J. Fish. Aquat. Sci. 43: 288-292.

Stockdale, A., Tipping, E., Lofts, S., Fott, J., Garmo, Ø.A., Hruska, J., Keller, B., Löfgren, S., Maberly, S.C., Majer, V., Nierzwicki-Bauer, S.A., Persson, G., Schartau, A-K., Thackeray, S.J., Valois, A., Vrba, J., Walseng, B., and Yan, N. 2014. Metal and proton 
toxicity to lake zooplankton: application of a chemical speciation based modeling approach. Environ. Pollut. 186: 115-125.

Strecker, A.L., and Arnott, S.E. 2005. Impact of Bythotrephes invasion on zooplankton communities in acid-damaged and recovered lakes on the Boreal Shield. Can. J. Fish. Aquat. Sci. 62: 2450-2462.

Strecker, A., Arnott, S.E., Yan, N.D., and Girard, R. 2006. Variation in response of crustacean zooplankton species richness and composition to the invasive predator Bythotrephes longimanus. Can. J. Fish. Aquat. Sci. 63: 2126-2136.

Szkokan-Emilson, E., Wesolek, B.E., and Gunn, J.M. 2011. Terrestrial organic matter as subsidies that aid in the recovery of macroinvertebrates in industrially damaged lakes. Ecol. Appl. 21: 2082-2093.

Szkokan-Emilson, E., Kielstra, B.W., Watmough, S.A., and Gunn, J.M. 2013. Drought-induced release of metals from peatlands in watersheds recovering from historical metal and sulphur deposition. Biogeochemistry, 116: 131-145.

Szkokan-Emilson, E., Watmough, S.A., and Gunn, J.M. 2014. Wetlands as long-term sources of metals to receiving waters in mining-impacted landscapes. Environ. Pollut. 192C: 91103.

Szkokan-Emilson, E., Kielstra, B.W., Arnott, S.E., Watmough, S.A., Gunn, J.M., and Tanentzap, A.J. 2017. Dry conditions disrupt terrestrial-aquatic linkages in northern catchments. Global Change Biol. 23: 117-126. 
1062 1063 1064 1065 1066 1067 1068 1069 1070 1071 1072 1073 1074 1075 1076 1077 1078 1079 1080 1081

Tanentzap, A.J., Taylor, P.A., Yan, N.D., and Salmon, J.R. 2007. On Sudbury-area wind speeds: a tale of forest regeneration. J. Appl. Meteorol. Clim. 46: 1645-1654.

Tanentzap, A.J., Yan, N.D., Keller, W., Girard, R., Heneberry, J., Gunn, J.M., Hamilton, D.P., and Taylor, P.A. 2008. Cooling lakes while the world warms: effects of forest re-growth and increased dissolved organic matter on the thermal regime of a temperate urban lake. Limnol. Oceanogr. 53: 404-410.

Tanentzap, A.J., Szkokan-Emilson, E.J., Kielstra, B.W., Arts, M.T., Yan, N.D., and Gunn, J.M. 2014. Forests fuel fish growth in freshwater deltas. Nature Communications, 5: 4077.

Taylor, N.S., Kirwan, J.A., Yan, N.D., Viant, M.R., Gunn, J.M., and McGeer, J.C. 2016a. Metabolomics confirms that dissolved organic carbon mitigates copper toxicity. Environ. Toxicol. Chem. 35(3): 635-644.

Taylor, N.S., Kirwan, J.A., Johnson, C., Yan, N.D., Viant, M.R., Gunn, J.M, and McGeer. J.C. 2016b. Predicting chronic copper and nickel reproductive toxicity to Daphnia pulexpulicaria from whole-animal metabolic profiles. Environ. Pollut. 212: 325-329.

Tropea, A.E., Paterson, A.M., Keller, W., and Smol, J.P. 2010. Sudbury sediments revisited: evaluating limnological recovery in a multiple stressor environment. Water Air Soil Pollut. 210: $317-333$.

Tropea, A.E., Paterson, A.M., Keller, W., and Smol, J.P. 2011. Diatoms as indicators of long-term nutrient enrichment in metal contaminated lakes from Sudbury, Ontario. Lake Reserv. Manage. 27: 48-60. 
1082

1083

1084

1085

1086

1087

1088

1089

1090

1091

1092

1093

1094

1095

1096

1097

1098

1099

1100

1101

1102

1103

Valois, A., Keller, W., and Ramcharan, C. 2010. Abiotic and biotic processes in recovering lakes: the role of metal toxicity and fish predation as barriers to zooplankton recovery. Freshwater Biol. 55: 2585-2597.

Valois, A., Keller, W., and Ramcharan, C.W. 2011. Recovery in a multiple stressor environment: using the reference condition approach to examine zooplankton community change along opposing gradients. J. Plankon Res. 33: 1417-1429.

Vandermeulen, H., Jackson, M.B., Rodrigues, A., and Keller, W. 1993. Filamentous algal communities in Sudbury area lakes: effects of variable lake acidity. Crypto. Bot. 3: 123132.

Vander Zanden, J., Wilson, K.A., Casselman, J.M., and Yan, N.D. 2004. Species introductions and their impacts in North American shield lakes. In Boreal Shield watersheds - lake trout ecosystems in a changing environment. Editors J.M. Gunn, R.J. Steedman, and R.A. Ryder Boca Raton: CRC.pp. 239-263,

Van Zuiden, T.M., Chen, M.M., Stefanoff, S., Lopez, L., and Sharma, S. 2016. Projected impacts of climate change on three freshwater fishes and potential novel competitive interactions. Diversity Distrib. 22: 603-614. doi 10.1111/ddi.12422.

Vuorenmaa, J., Augustaitis, A., Beudart, B., Bochenek, W., Clarke, N., de Wit, H., Dirnböck, T., Frey, J., Hakola, H., Kleemola, S., Kobler, J., Kŕam, P., Lindroos, A-J., Lundin, L., Löfgren, S., Marchetto, A., Pecka, T., Schultei-Bisping, H., Skotak, K., Srybny, A., Szpikowski,'J., Ukonmaanaho, L., V́aňa, M., Akerblom, S., and Forsius, M. 2018. Longterm changes (1990-2015) in the atmospheric deposition and runoff water chemistry of sulphate, inorganic nitrogen and acidity for forested catchments in Europe in relation to 

changes in emissions or hydrometeorological conditions. Sci. Total Environ. 625: 11291145.

Watmough, S.A., and Aherne, J. 2008. Estimating calcium weathering rates and future lake calcium concentrations in the Muskoka-Haliburton area of Ontario. Can. J. Fish. Aquat. Sci. 65(5): 821-833.

Watson, G., Hunt, C., and Keller, W. 1999. Natural and enhanced aquatic ecosystem development at Inco's former Garson 10.2 open pit mine. In Proc. Mining and the Environment II, Sudbury, Ontario. Edited by D. Goldsack, N. Belzile, P. Yearwood, and G. Hall. pp. 419-

Webster, N.I., Keller, W., and Ramcharan, C. 2013. Restoration of zooplankton communities in 428.

Wesolek, B.E., Genrich, E.K., and Gunn, J.M. 2010a. Use of littoral benthic invertebrates to assess factors affecting biological recovery of acid and metal damaged lakes. J. N. Am. Benthol. Soc. 29(2): 572-585.

Wesolek, B.E., Gunn, J.M., Sarrazin-Delay, C., Bedore, J., Chan, F., Garreau, D., O’Grady, A., and Robinson, C. 2010b. Recovery of benthic invertebrate communities from acidification in Killarney Park lakes. Environ. Monit. Assess. 166: 293-302.

1122 White, C., Sayer, J.A., and Gadd, G.M. 1997. Microbial solubilization and immobilization of toxic metals: key biogeochemical processes for treatment of contamination. FEMS Microbial. Rev. 20: 1-17. 
1125 Williamson, C.E., Stemberger, R.S., Morris, E.P., Frost, T.M., and Paulsen, S.G. 1996.

1126

1127

1128

1129

1130

1131

1132

1133

1134

1135

1136

1137

1138

1139

1140

1141

1142

1143

1144

1145

Ultraviolet radiation in North American lakes: Attenuation estimates from DOC measurements and implications for plankton communities. Limnol. Oceanogr. 41: 10241034.

Williamson, C.E, Overholt, E.P, Pilla, R.M., Leach, T.H., Brentrup, J.A., Knoll, L.B., Mette, E.M., and Moeller, R.E. 2015. Ecological consequences of long-term browning in lakes. Nature Scientific Reports, 5: 18666 DOI:10.1038/srep18666.

Winter, J.G., Keller, W., Paterson, A.M. and Yan, N.D. 2008. Three decades of recovery of the phytoplankton community in Clearwater Lake (Sudbury, Canada) from acid and metal contamination. Verh. Internat. Verein. Limnol. 30, part 2: 247-252.

Winterhalder, K. 1995a. Early history of human activities in the Sudbury area and ecological damage to the landscape. In Restoration and recovery of an industrial region. Edited by J.M. Gunn. Springer Verlag. pp. 17-31.

Winterhalder, K. 1995b. Natural recovery of vascular plant communities in the industrial barrens of the Sudbury area. In Restoration and recovery of an industrial region. Edited by J.M. Gunn. Springer Verlag. pp. 93-102.

Winterhalder, K. 1995c. Dynamics of plant communities and soils in revegetated ecosystems: a Sudbury case study. In Restoration and recovery of an industrial region. Edited by J.M. Gunn. Springer Verlag. pp. 173-182.

Winterhalder, K. 1996. Environmental degradation and rehabilitation of the landscape around Sudbury, a major mining and smelting area. Environ. Rev. 4: 185-224. 
1146 Woodfine, D.G., and Havas, M. 1995. Pathways of chemical recovery in acidified metal1147 contaminated lakes near Sudbury, Ontario, Canada. Water Air Soil Pollut. 85: 797-803.

1148 Yan, N.D. 1979. Phytoplankton community of an acidified, heavy metal-contaminated lake near 1149 Sudbury, Ontario: 1973-1977. Water Air Soil Pollut. 11: 43-55.

1150 Yan, N.D., and Geiling, W. 1985. Elevated planktonic rotifer biomass in acidified metal1151 contaminated lakes near Sudbury, Ontario. Hydrobiologia, 120: 199-205.

1152 Yan, N.D., and Stokes, P. 1978. Phytoplankton of an acidic lake, and its responses to 1153 experimental alterations of pH. Environ. Conserv. 5: 93-100.

1154 Yan, N.D., and Strus, R. 1980. Crustacean zooplankton communities of acidic, metal1155 contaminated lakes near Sudbury, Ontario. Can. J. Fish. Aquat. Sci. 37: 2282-2293.

1156 Yan, N.D., Keller, W., Pitblado, J.R., and Mackie, G.L. 1988. Daphnia-Holopedium 1157 relationships in Canadian Shield lakes ranging in acidity. Verh. Internat. Verein. Limnol.

1159 Yan, N.D., Keller, W., MacIsaac, H.J., and McEachern, L.J. 1991. Regulation of zooplankton 1160 community structure of an acidified lake by Chaoborus. Ecol. Appl. 1: 52-65.

1161 Yan, N.D., Keller, W., and Gunn, J.M. 1995. Liming of Sudbury lakes: Lessons for recovery of 1162 1163 aquatic biota from acidification. In Restoration and recovery of an industrial region. Edited by J.M. Gunn. Springer Verlag. pp. 195-204.

1164 Yan, N.D., Keller, W., Scully, N.M., Lean, D.R.S., and Dillon, P.J. 1996a. Increased UV-B 1165 penetration in a lake owing to drought-induced acidification. Nature, 381: 141-143. 
1166 Yan, N.D., Welsh, P.G., Lin, H., Taylor, D.J., and Filion, J.M. 1996b. Demographic and genetic

1167

1168

1169

1170

1171

1172

1173

1174

1175

1176

1177

1178

1179

1180

1181

1182

1183

1184

1185

evidence of the long-term recovery of Daphnia galeata mendotae (Crustacea; Daphnidae) in Sudbury lakes following additions of base: the role of metal toxicity. Can. J. Fish. Aquat. Sci. 53: $1328-1344$.

Yan, N.D., Keller, W., Somers, K.M., Pawson, T.W., and Girard, R. 1996c. Recovery of crustacean zooplankton from acid and metal contamination: comparing manipulated and reference lakes. Can. J. Fish. Aquat. Sci. 53: 1301-1327.

Yan, N.D., Leung, B., Keller, W., Arnott, S.E., Gunn, J.M., and Raddum, G. 2003. Developing conceptual ecological frameworks for the recovery of aquatic biota from acidification. Ambio, 32: 165-169.

Yan, N.D., Girard, R., Heneberry, J., Keller, W., Gunn, J., and Dillon, P.J. 2004. Recovery of copepod, but not cladoceran, zooplankton from severe and chronic effects of multiple stressors. Ecology Letters, 7: 452-460.

Yan, N.D., Paterson, A.M., Somers, K.M., and Scheider, W.A. 2008a. An introduction to the Dorset special issue: transforming understanding of factors that regulate aquatic ecosystems on the southern Canadian Shield. Can. J. Fish. Aquat. Sci. 65: 781-785.

Yan, N.D., Somers, K.M., Girard, R.E., Paterson, A.M., Keller, W., Ramcharan, C.W., Rusak, J.A., Ingram, R., . Morgan, G., and Gunn, J.M. 2008b. Long-term trends in zooplankton of Dorset, Ontario lakes: the probable interactive effects of changes in $\mathrm{pH}, \mathrm{TP}, \mathrm{DOC}$ and predators. Can. J. Fish. Aquat. Sci. 65: 862-877. 
1186 Yan, N.D., Bailey, J., McGeer, J., Manca, M., Keller, W., Celis-Salgado, M., and Gunn, J.M.

1187 2016. Arrive, survive, and thrive: the essential stages of re-colonization and recovery of zooplankton in urban lakes in Sudbury, Canada. J. Limnol. 75(s2): 4-14.

1190 Appendix

1191 Appendix Figs. A1 to A4 are provided on the following pages. 


\section{Figure captions}

1198 Fig. 1. Locations of key Sudbury area lakes monitored by the Ontario Ministry of the 1199 Environment, Conservation and Parks. "Extensive" monitoring lakes are sampled once annually, 1200 in summer, for chemistry, and in some years for zooplankton. "Intensive" monitoring lakes are 1201 sampled at least monthly during the ice-free season for chemistry, phytoplankton, zooplankton, 1202 and oxygen and thermal structure. Long-term chemistry trend data presented in this paper are 1203 primarily from the Extensive monitoring lakes; however, chemical and biological changes in 1204 various Intensive monitoring lakes are described in the text.

1205 Fig. 2. Linear mixed-effect model slopes describing the observed temporal trends over the period 1206 1981-2015 for $\mathrm{pH}(\mathrm{a}), \mathrm{SO}_{4}$ (b), $\mathrm{Ca}$ (c) and DOC (d) for 42 Extensive monitoring lakes shown in 1207 Fig 1. Slopes are presented in rank order and display the 95\% confidence interval for each lake. 1208 Lake specific slope was calculated as the conditional mean random effect slope, and standard 1209 error for each lake was calculated as the standard error of the conditional mean of each random 1210 effect slope. The 95\% CI was then calculated as the mean slope $+/-1.96$ times its standard error. 1211 Slopes were deemed significant if their 95\% CI did not overlap zero. CI's for $\mathrm{SO}_{4}$ are too narrow 1212 to show at this scale. All lakes had increases in $\mathrm{pH}$ and decreases in $\mathrm{SO}_{4}$ and $\mathrm{Ca}$ over this period. 1213 All but five lakes had increases in DOC.

1214 Fig. 3. Relationships of lakewater $\mathrm{SO}_{4}$ (a), $\mathrm{Ni}$ (b) $\mathrm{Cu}$ (c) and $\mathrm{Al}$ (d) (total concentrations for 1215 metals) with distance from the Sudbury smelters, in 2015, for the Extensive and Intensive 1216 monitoring lakes (based on single summer samples). Three additional lakes not shown in Fig. 1 1217 (Bowland, Silver, Whitson) were added to the dataset. Provincial Water Quality Objectives 
1218 (PWQO, MOEE 1994) for total $\mathrm{Ni}$ and $\mathrm{Cu}$ are shown. The PWQO for Al in such dilute lakes is 1219 based on inorganic Al, which has not been measured. For comparison to the Sudbury lakes, the 1220 range in $\mathrm{SO}_{4}$ concentrations in eight Dorset, Ontario lakes in July 2015 is also shown in panel a 1221 (horizontal dashed lines).

1222 Fig. A1. Time series for $\mathrm{pH}$ for 42 Extensive monitoring lakes sampled once annually in the 1223 summer epilimnion, 1981-2015.

1224 Fig. A2. Time series for $\mathrm{SO}_{4}$ for 42 Extensive monitoring lakes sampled once annually in the 1225 summer epilimnion, 1981-2015.

1226 Fig. A3. Time series for $\mathrm{Ca}$ for 42 Extensive monitoring lakes sampled once annually in the 1227 summer epilimnion, 1981-2015.

1228 Fig. A4. Time series for dissolved organic carbon (DOC) for 42 Extensive monitoring lakes 1229 sampled once annually in the summer epilimnion, 1981-2015. 
$81^{\circ} 0^{\prime} \mathrm{O}^{\prime \prime} \mathrm{W}$

$80^{\circ} 0^{\prime} \mathrm{O}^{\prime \prime} \mathrm{W}$

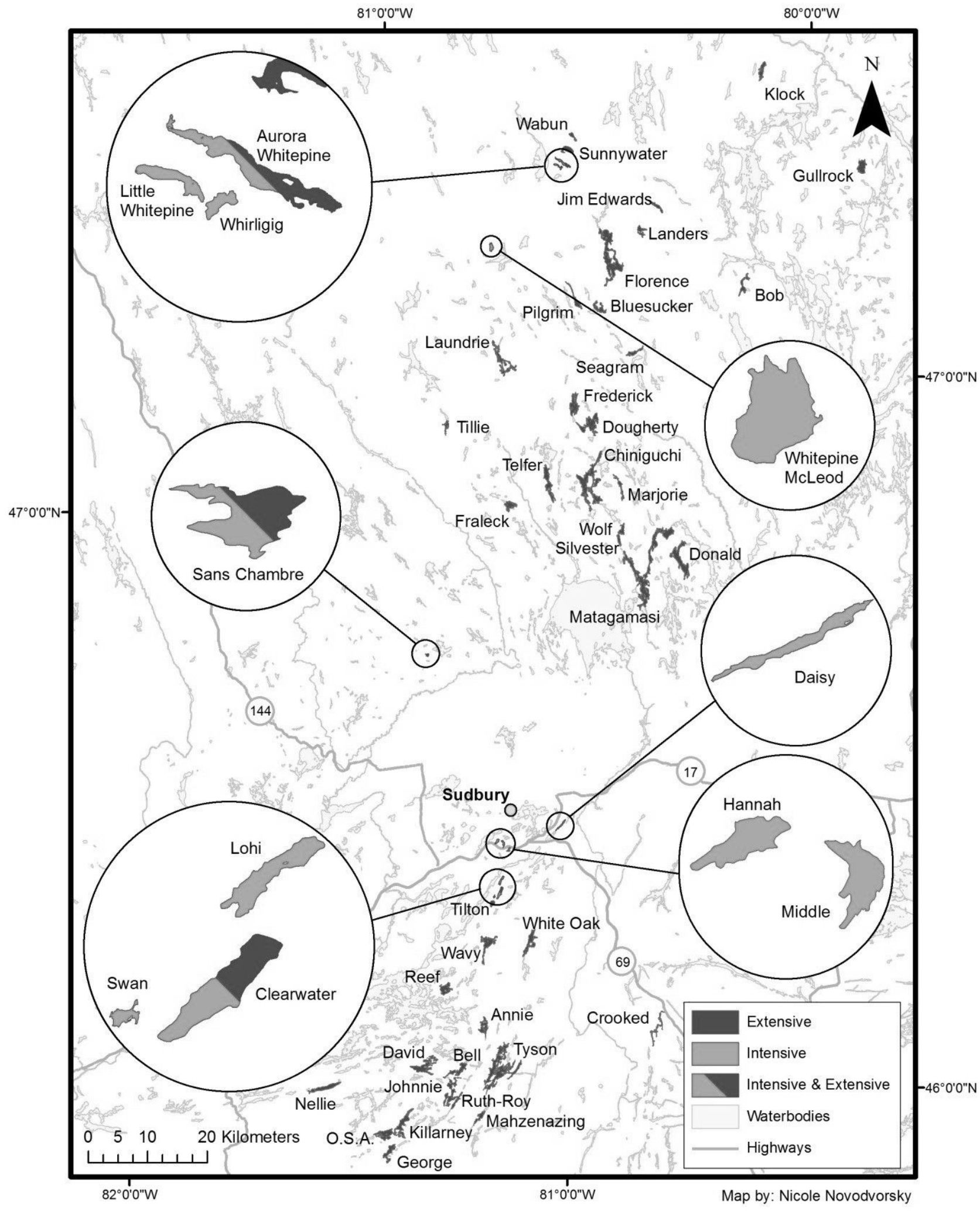

Keller et al. Fig. 1. 


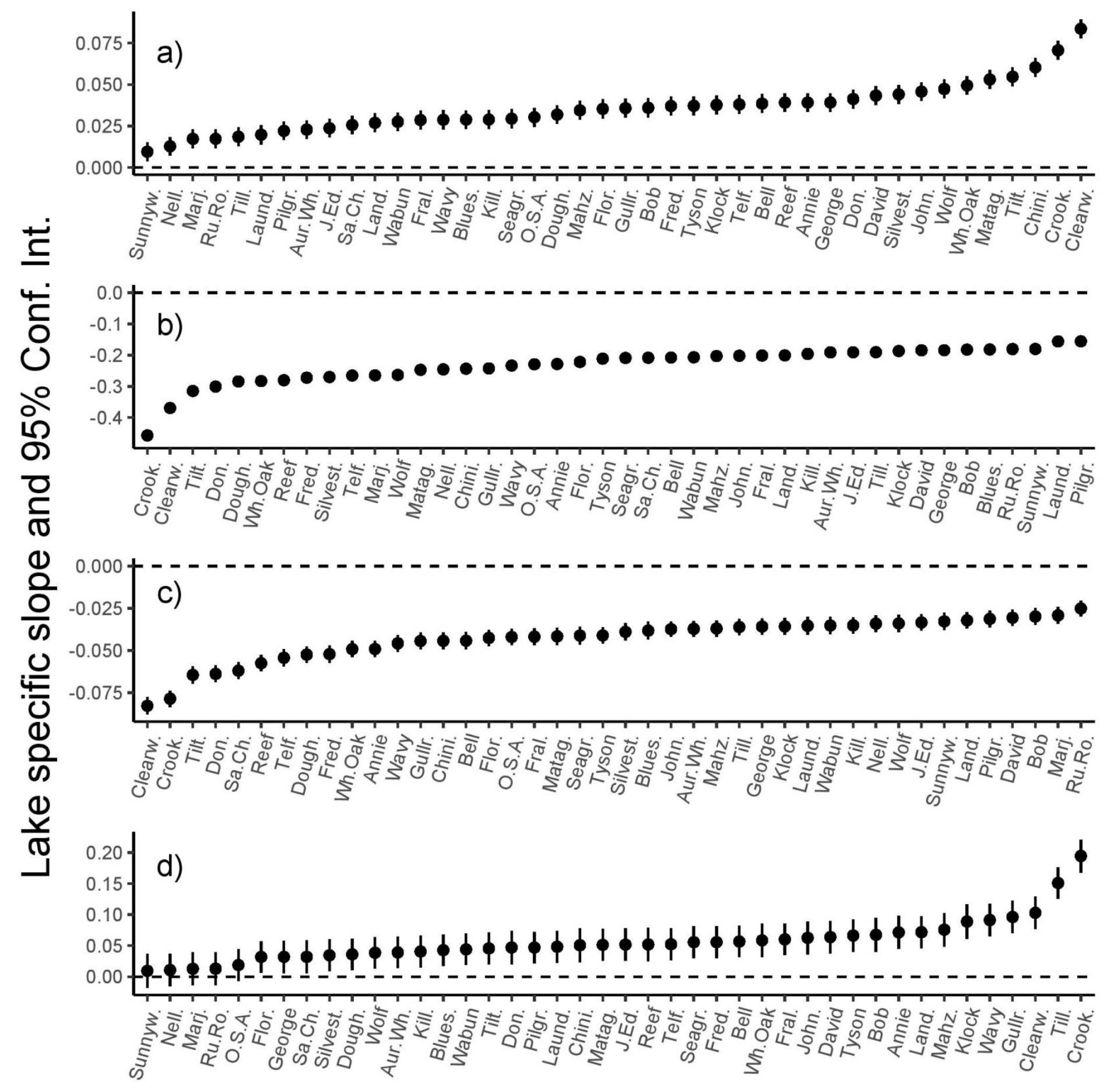

Keller et al. Fig. 2. 

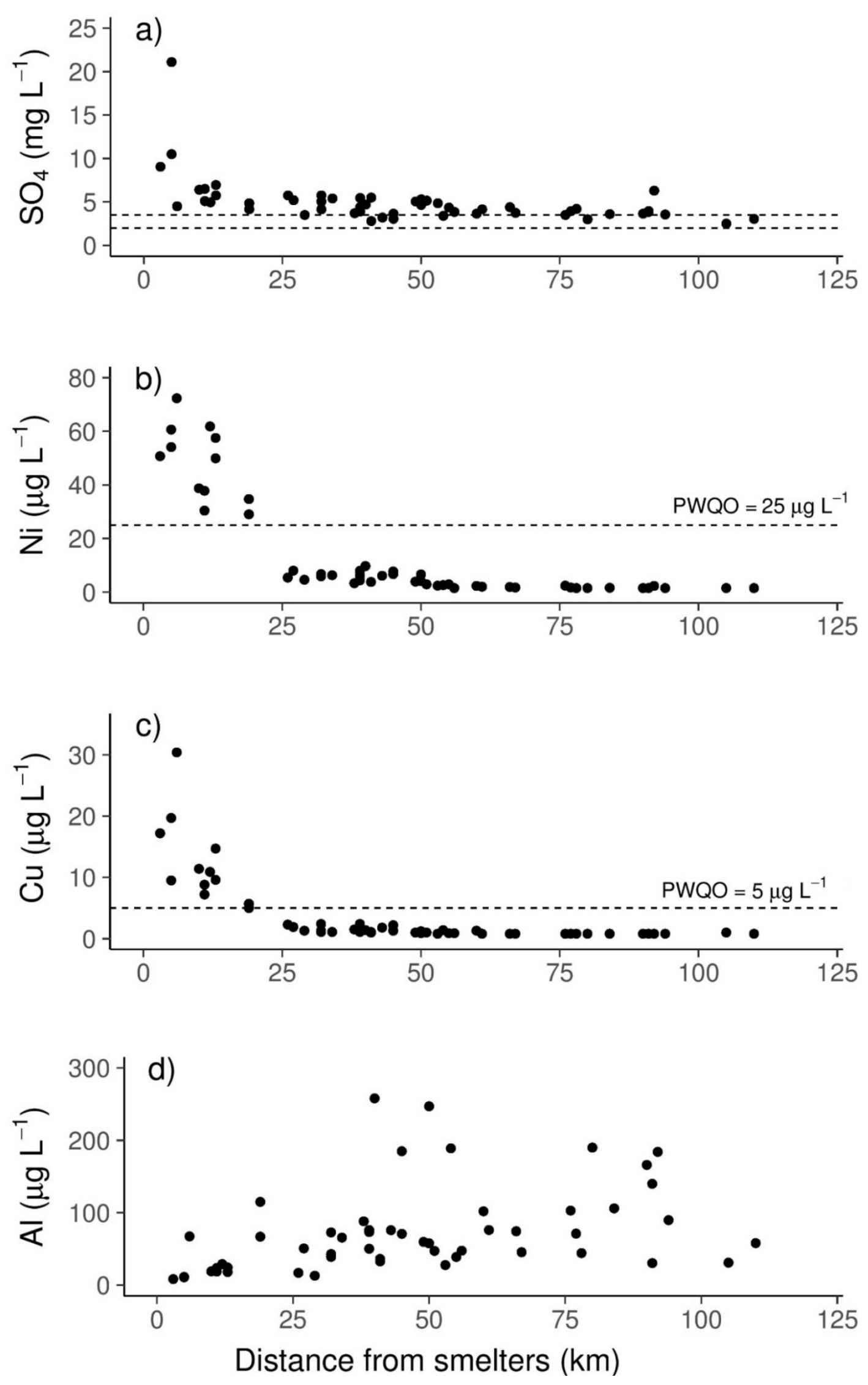

Keller et al. Fig. 3 
Table 1. List of abbreviations for the Extensive monitoring lakes shown in Fig. 2 and the Appendix.

\begin{tabular}{llll}
\hline Name & Abbreviation & Name & Abbreviation \\
\hline Annie & Annie & Laundrie & Laund. \\
Aurora Whitepine & Aur. Wh. & Mahzenazing & Mahz. \\
Bell & Bell & Marjorie & Marj. \\
Bluesucker & Blues. & Matagamasi & Matag. \\
Bob & Bob & Nellie & Nell. \\
Chiniguchi & Chini. & O.S.A. & O.S.A.. \\
Clearwater & Clearw. & Pilgrim & Pilgr. \\
Crooked & Crook. & Reef & Reef \\
David & David & Ruth Roy & Ru.Ro. \\
Donald & Don. & Sans Chambre & Sa.Ch. \\
Dougherty & Dough. & Seagram & Seagr. \\
Florence & Flor. & Silvester & Silvest. \\
Fraleck & Fral. & Sunnywater & Sunnyw. \\
Frederick & Fred. & Telfer & Telf. \\
George & George & Tillie & Till. \\
Gullrock & Gullr. & Tilton & Tilt. \\
Jim Edwards & J.Ed. & Tyson & Tyson \\
Johnnie & John. & Wabun & Wabun \\
Killarney & Kill. & Wavy & Wavy \\
Klock & Klock & White Oak & Wh.Oak \\
Landers & Land. & Wolf & Wolf \\
\hline & & & \\
\hline
\end{tabular}

